Krystian Heffner

\title{
Proces suburbanizacji a polityka miejska w Polsce
}

Rozwój miast w Polsce, rozumiany jako proces przemian ich struktury społeczno-gospodarczej i przestrzennej, charakteryzuje się bardzo zróżnicowaną intensywnościa, a także zakresem przekształceń, w zależności od położenia w przestrzeni i ulokowania w hierarchii regionalnej, krajowej i międzynarodowej. Miasta rozwijają się jako centra zarządzania i organizacji różnych instytucji sektora publicznego i prywatnego określonych poziomów oraz obszarów, ale również jako składowe układów terytorialnych różnej skali. Ośrodki miejskie, stanowiące ciała samorządowe, prowadzą własną politykę rozwoju, która z oczywistych względów jest polityką preferencji miejskich celów rozwoju przed celami regionalnymi i krajowymi. Są również składową (często wiodącym składnikiem) polityk terytorialnych, uwzględniających szersze, obszarowe uwarunkowania i oddziaływania. To właśnie ten typ polityki, odnoszący się do obszarów funkcjonalnych, uwzględniający często rozbieżne cele rozwoju - jest polem, na którym polityka miejska spotyka się z politykami rozwoju obszarów wiejskich, zrównoważonego rozwoju, bezpieczeństwa energetycznego i ochrony klimatu, wreszcie z politykami rozwoju innych miast i innych regionów. $W$ takim sensie proces suburbanizacji jest jednym $\mathrm{z}$ wielu składników polityki regionalnej i polityk lokalnych (rozumianych jako polityka rozwoju obszarów wiejskich). Jako polityka terytorialna jest traktowana jako regionalna polityka miejska, łącząca rozwój miast z ich obszarami oddziaływania i obszarami wzajemnych, często rozbudowanych, relacji.

$\mathrm{W}$ artykule podjęto próbę oceny zjawiska suburbanizacji, tak z punktu widzenia celów polityki regionalnej, jak i innych polityk oddziałujących bezpośrednio na kierunki rozwoju obszarów wiejskich znajdujących się w otoczeniu miast (np. polityki rozwoju obszarów wiejskich). Wskazano też - posługując się przykładem województwa śląskiego - główne uwarunkowania tego procesu, a także podjęto próbę sformułowania rekomendacji dla polityki miejskiej prowadzonej na poziomie regionalnym. 


\section{Polityka miejska i suburbanizacja}

Polityka miejska jest ukierunkowana terytorialnie, stanowi integralną część polityki rozwoju społecznego, gospodarczego i przestrzennego kraju i regionów. Polega na świadomej i celowej działalności podmiotów publicznych, które kształtują rozwój społeczny, gospodarczy i przestrzenny funkcjonalnych obszarów miejskich. Jest realizowana na wszystkich poziomach zarządzania: krajowym, regionalnym oraz lokalnym, a jej adresatami są aktorzy publiczni i niepubliczni, prowadzący działania istotne dla osiągania celów tej polityki (Pankau 2011).

Potrzeba prowadzenia polityki odnoszącej się do rozwoju i kształtowania miast na poziomie regionalnym wynika, z jednej strony, z zauważanej konieczności wskazania głównych wyzwań dla europejskich miast w sensie globalnym oraz sposobów organizacji przestrzeni i funkcjonowania społeczeństwa. Z drugiej strony, regionalna polityka miejska koncentruje się na kształtowaniu struktury przestrzennej regionu, odpowiadającej regionalnym i lokalnym potrzebom, umożliwiającej wdrażanie innych, ważnych polityk sektorowych.

Koncepcja krajowej polityki miejskiej w Polsce bezpośrednio łączy się z szeroką debatą nad rozwojem i rolą miast w krajach Unii Europejskiej

76 (Sługocki 2011). Dyskusja dotyczy spójności terytorialnej (nowy wymiar polityki spójności po $2013 \mathrm{r}$. i wzmocnienie w niej problematyki miejskiej), terytorializacji polityk publicznych, $\mathrm{w}$ tym reasumpcji roli miast we wspomaganiu nowej polityki spójności, która przewartościowuje znaczenie regionów i państw w jej prowadzeniu. Komisja Europejska podkreśla znaczenie miast i preferuje podejście funkcjonalne, łączące centra miejskie $z$ terenami zewnętrznymi (obejmującymi strefy suburbanizacji) w obszary miejskie, które - jako struktury o powiększonym potencjale - mogą być motorami wzrostu i platformami kreatywności oraz innowacji. Sugeruje się, że problemy miast, niezależnie od tego, czy dotyczą degradacji środowiska, czy wykluczenia społecznego, potrzebują realnych rozwiązań i bezpośredniego zaangażowania organów właściwego szczebla, które będą przygotowywać programy rozwoju miast z przejrzystymi wskazaniami środków finansowych, przeznaczonych na zagadnienia miejskie. Również władze miejskie miałyby odgrywać większą rolę w projektowaniu i wdrażaniu strategii rozwoju obszarów miejskich. Zaproponowano, aby w dokumentach programowych nowej polityki spójności jasno określić działania dotyczące miast, stosowne środki oraz listę wybranych miast (Wnioski... 2010).

Nie ulega wątpliwości, że stwierdzenia te odnoszą się de facto do największych miast lub miast o szczególnym statusie (politycznym - stolice krajów, regionów; gospodarczym, społeczno-kulturowym), jednak również $\mathrm{z}$ istotnym potencjałem ludnościowym. $\mathrm{W}$ takim sensie ( $\mathrm{w}$ świetle 
powstających w ostatnich latach dokumentów i opracowań, m.in. w Polsce Krajowa Strategia Rozwoju Regionalnego 2010-2020: Regiony, Miasta, Obszary Wiejskie, Koncepcja Przestrzennego Zagospodarowania Kraju 2030) strefy zewnętrzne miast, często ze stosunkowo słabo zaawansowanymi procesami suburbanizacji, ale funkcjonalnie powiązane $\mathrm{z}$ obszarami centralnymi aglomeracji miejskich - stają się składowymi powiększającymi potencjał ośrodków miejskich. Ma to szczególne znaczenie w sytuacji masowego przesuwania się populacji (głównie większych miast europejskich) w kierunku ich obszarów zewnętrznych, najczęściej w sposób żywiołowy, co prowadzi do niekontrolowanego osłabiania składowych wzrostu miejskiego (Brake i in. 2001; Palang, Peil 2010: 700-710).

Krajowa polityka miejska ma wzmacniać zdolności miast i obszarów zurbanizowanych do kreowania zrównoważonego rozwoju oraz tworzenia miejsc pracy, a także poprawiać jakość życia mieszkańców i nawiązywać do celów wskazanych w innych krajowych dokumentach strategicznych. Jej prowadzenie oznacza planowane działania administracji rządowej, służące ukierunkowanemu terytorialnie działaniu państwa na rzecz zrównoważonego rozwoju miast $\mathrm{z}$ obszarami funkcjonalnymi oraz wykorzystaniu ich potencjałów w procesach rozwoju kraju (Krajowa Polityka... 2014). Można przyjąć, że jest to próba integracji obszarów miejskich, a więc potraktowania strefy zurbanizowanej lub urbanizującej się poza formalnym obszarem miasta (strefa suburbanizacji) jako istotnej składowej organizmu miejskiego. W takim ujęciu, nie jest to obszar wiejski - zewnętrzny w stosunku do miasta, rozwijający się w oparciu o własne wyzwania i cele rozwojowe. Strategiczne cele rozwoju strefy suburbanizacji niekoniecznie muszą być tożsame z priorytetami miasta, metropolii (Tacoli 2003: 3-12; Heffner, Gibas 2014).

W Polsce polityka miejska powinna przede wszystkim podtrzymywać zwartość miast (idea compact city - por. szeroką dyskusję na ten temat w literaturze anglosaskiej, również polskiej, np. Breheny 2003: 10-29; Delden van 2011: 154-172; Saaty 2013: 85-91; Polit 2010: 85-91), a więc zapewniać bodźce do preferowania działań intensyfikujących wykorzystanie miejskiej przestrzeni i hamować proces rozprzestrzeniania miejskich form użytkowania terenu na obszary wiejskie (w tym rolne i cenne środowiskowo). Istotne jest dążenie do spójności wewnętrznej miasta poprzez eliminację poszczególnych obszarów wykluczenia, zarówno w sensie ekonomicznym, jak i społecznym oraz zapewnienie aktywnego wykorzystania przestrzeni publicznych, polegające na zwiększeniu atrakcyjności miasta dla jego mieszkańców oraz użytkowników zewnętrznych (Dziekoński 2008). Nie wszystkie proponowane kierunki działań (m.in. metropolie, nowa polityka miejska) są w pełni przygotowane, tak od strony odbiorców proponowanych polityk - samorządów regionalnych, lokalnych, układów 
sektorowych, jak i od strony praktycznej - np. rozwiązania ustawowe, zakres dyskusji nad szczegółami, przedmiot działań. Proponuje się m.in. audyt urbanistyczny dla oceny alternatyw rozwoju.

Przyjęty model zarządzania rozwojem Polski w okresie 2014-2020 opiera się na zespoleniu wymiaru społeczno-gospodarczego i terytorialnego, ma też zapewniać spójność wszystkich polityk sektorowych, dziedzinowych i regionalnych przy zaangażowaniu całej administracji publicznej i zintegrowanym podejściu terytorialnym. Podejmowane działania są pochodną obowiązujących krajowych dokumentów strategicznych, z równoczesnym wykorzystaniem doświadczeń europejskich i dążeniem do wzmocnienia wymiaru miejskiego polityki regionalnej. Oznacza to, że krajowa polityka miejska została przygotowana na podstawie oceny przekraczającego dekadę okresu funkcjonowania samorządu terytorialnego. Ponadto poprzez dyskusję o nowym, wieloszczeblowym i terytorializowanym systemie zarządzania, w którym proponowano metropolie jako nowych aktorów tej struktury, podjęto próbę wskazania głównych celów i zasad prowadzenia tej polityki (Żuber 2011).

\section{Proces suburbanizacji - definicje, geneza i powiązania}

Procesy suburbanizacji jako zjawisko przestrzenne mają charakter lokalny. Przekształcenia struktur osadniczych i społeczno-gospodarczych zachodzą bowiem w wiejskim otoczeniu miast pod wpływem ich głównie ekonomicznego oddziaływania. Strefy miejskie, obejmujące obszary powiązane z centrum, zarówno ekonomicznie, jak i społecznie, a także kulturowo, szczególnie w wypadku miast większych - mają regionalne oddziaływanie i znaczenie, stając się ważnym czynnikiem kształtowania społecznych funkcji regionu i jego gospodarki. W wypadku metropolii, rozległe strefy suburbanizacji, wzmacniające ich potencjał, mogą tworzyć struktury typu regionalnego, o oddziaływaniach krajowych i międzynarodowych. Często suburbanizacja jest traktowana jako zjawisko nieuchronne (Heffner 2008: 51-71; Bagiński 2001: 11-16).

Urbanizacja strefy podmiejskiej (miejscowości wiejskich w pobliżu miasta, dróg, użytków rolnych, lasów itd.) polega na przekroczeniu przez miejskie użytki formalnych granic miasta i rozszerzeniu miejskości. Często są to obszary formalnie włączane do miast (Liszewski 1987: 65-80). Powszechnie traktuje się suburbanizację jako etap procesu urbanizacji, jednak trudno określić, co jest charakterystyczne dla tej właśnie fazy, gdyż jest postrzegana jako zjawisko wielowymiarowe i złożone, a wskazanie cech jednoznacznie wyróżniających ten proces jest niemożliwe (Zuziak 2005: 17-33; Straszewicz 1959: 69-91). 
Innym podejściem do procesu suburbanizacji jest identyfikowanie go jako zjawiska polegającego na migracji użytkowników miasta (mieszkańców, podmiotów gospodarczych, instytucji sektora publicznego, ośrodków usługowych, handlowych, sektora badawczo-rozwojowego itd.) ze strefy centralnej na przedmieścia, często poza granice administracyjne ośrodka miejskiego. Jest to efekt decyzji lokalizacyjnych, które wynikają z pogarszających się warunków funkcjonowania w centrum miasta, rosnących kosztów i braku możliwości rozwojowych, związanych z ograniczeniami przestrzennymi. W wielu opracowaniach łączy się to zjawisko z procesem rozgęszczania (dezurbanizacji) strefy centralnej miasta (Walker 1981: 383-429).

Suburbanizacja jest ponad to odkreślana jako proces, w którym wzrost liczby mieszkańców i miejsc pracy na obszarach podmiejskich jest szybszy niż w mieście centralnym. W takim ujęciu różnicowanie tempa wzrostu ludności w całym obszarze zurbanizowanym wiąże się z modelem cyklu życiowego miasta, w którym ośrodek miejski przechodzi kolejne fazy rozwoju (Burdack, Hesse 2006: 381-399), a suburbanizacja, jako drugi etap, cechuje się zdecydowanym przyspieszeniem przyrostu ludności na obszarach zewnętrznych. Trzecią fazą jest proces dezurbanizacji. Wówczas liczba ludności w strefie miasta centralnego wyraźnie spada i jest znacząco niższa niż przyrost populacji na obszarach zewnętrznych. Wejście w tę fazę ma kluczowe znaczenie dla rozwoju miasta jako obszaru miejskiego, wskazując potencjał i możliwości rozwojowe ośrodka w relacjach i układach zewnętrznych (gospodarczych, politycznych, przestrzennych). Klasyczny cykl zamyka faza reurbanizacji, polegająca na "powrocie” i ponownym zasiedleniu obszarów centralnych miast. Przypomina pierwsze etapy urbanizacji ze względu na zmiany w użytkowaniu obszaru miejskiego, rewitalizację niektórych części miasta, a także zjawisko gentryfikacji (Kajdanek 2011; Heffner, Marszał 2011: 5-7; Parysek 2008: 281-286; Sieverts 2003). Obszary zewnętrzne, zurbanizowane i przekształcone pod wpływem związków z miastem, nie powracają do pierwotnego stanu (np. monofunkcyjności rolniczej), pozostają natomiast w ścisłym powiązaniu z miastem i przechodzą przekształcenia typu funkcjonalnego oraz racjonalizującego wykorzystanie potencjału (np. wielofunkcyjne obszary wiejskie).

Tradycyjnie, urbanizacja wsi jest traktowana jako „proces upodobniania się wsi do miast, który prowadzi według różnych koncepcji, do zatarcia różnic między miastami $i$ wsiami w bliżej nieokreślonej przyszłości i zakresie" lub też jako "przemiany zdązajace do wyrównywania się dysproporcji w warunkach i sposobie życia między wsia a miastem", z natury rzeczy zjawisko to ma charakter żywiołowy, chociaż niektóre jego składniki (np. narastanie zabudowy) wpisują się $\mathrm{w}$ procedury planistyczne, są też regulowane mniej 
lub bardziej szczegółowymi przepisami, często spoza sfery planowania przestrzennego (Strzelecki, Kucińska 2006: 125-150). Procesy urbanizacyjne, jeśli obejmują tereny pozamiejskie, mogą być rozpatrywane z różnych punktów widzenia - funkcjonalnie, ekologicznie, w ujęciu społeczno-zawodowym, społeczno-kulturowym, ekonomicznym, krajobrazowym, ekologicznym itd. Właśnie tak szeroko rozumiane procesy urbanizacji wsi nazywane są suburbanizacją.

Terminem suburbanizacja określa się więc „szeroko pojmowane przemiany urbanizacyjne zachodzace w strefach podmiejskich, na obszarach wiejskich. Sa one powiazane z ośrodkiem centralnym, a czẹść z nich z czasem jest wchtaniana przez miasto". Jednak włączanie zurbanizowanych obszarów wiejskich (wsi) w formalną strukturę miast dokonywało się i dokonuje współcześnie w różnym tempie i według zasad odmiennych w poszczególnych krajach, a nawet okresach. Dlatego często zdarza się, że z jednej strony w układach miejskich (wewnątrz administracyjnego obszaru miasta) znajdują się tereny nie $w$ pełni zurbanizowane, $z$ drugiej, poza obszarami administracyjnymi miast, są obszary zabudowane i wsie całkowicie zurbanizowane, różniące się od struktur miejskich jedynie statusem formalnym, co oczywiście wywołuje wiele trudnych do rozwiązania konfliktów i problemów w sferze gospodarczej i społecznej oraz na gruncie planowania przestrzennego. Procesy tego typu mają również daleko idące konsekwencje fiskalne dla obszarów lokalnych, szczególnie wiejskich, ze względu na warunki finansowania aktywności i działalności gmin, na co od dawna zwraca się uwagę w wielu badaniach. Inny - niekoniecznie z lepszymi konsekwencjami dla mieszkańców - jest kierunek rozwoju samodzielnie funkcjonującej lokalnej struktury wiejskiej lub miejskiej w strefie suburbanizacji (np. dobrowolne uczestnictwo w celowych układach terytorialnych), a inny, gdy jej wzrost sterowany jest zewnętrznie (np. poprzez specjalnie tworzone szczeble organizacyjne zarządzania lub administrowania terytorium przykładowo: zarządy metropolii) lub odbywa się jako część inkorporowana do struktury aglomeracyjnej czy metropolitalnej. Równocześnie, ten zewnętrzny rozwój miasta, jego tempo i zakres jest ściśle powiązany nie tylko $\mathrm{z}$ procesami gospodarczymi i społecznymi zachodzącymi $\mathrm{w}$ centrum, a także ze zmieniającą się pozycją miasta w układach regionalnych, krajowych i międzynarodowych (Champion 2001: 143-161). Jest to wyraźne nawiązanie do koncepcji (modelu) faz rozwojowych miasta.

\section{Trendy wpływające na procesy suburbanizacji w regionach}

W opracowaniach dotyczących przestrzennych aspektów rozwoju miast, szczególnie dużych aglomeracji miejskich (metropolii), w coraz większym stopniu zwraca się uwagę na pogłębiający się proces komplika- 
cji rozwijających się układów miejskich, zarówno w sensie funkcjonalnym (przemieszanie funkcji miejskich, policentryczność), jak i społeczno-kulturowym i gospodarczym. Podkreślają to liczni badacze, m.in. amerykańscy, brytyjscy, niemieccy, a także polscy (por. Houtum van, Lagendijk 2001: 747-767; Lisowski, Grochowski 2009: 216-280; Heffner 2011b: 8-26). Struktura obszarów miejskich (regionów miejskich) staje się coraz bardziej policentryczna, a funkcje miejskie są stosunkowo równomiernie wymieszane z nowymi formami zagospodarowania, oddziałującymi nie tylko lokalnie, lecz także na całą strefę miejską.

Rozwój miast w strefach zewnętrznych, na obszarach wiejskich, przyjmuje współcześnie wiele form, które wcześniej nie występowały - tzw. miasta zewnętrzne (edge cities), osiedla typu park tematyczny (theme parks), osiedla zamknięte (gated communities), struktury konsumpcji (consumption opportunities), centra zarządzania (command and control centers). W pracach amerykańskich pojawia się opinia, że dojrzałą formą ponowoczesnego miasta jest policentryczna metropolia, której oddziaływanie wydaje się wszechobecne. Układ miejski nie ma określonych granic i rozrasta się intensywnie w niekontrolowany sposób w strefie zewnętrznej (suburbanizacja, urban sprawl; por. Bontje 2004: 25-47; Dear 2000; Czerny 2005). Począwszy od lat 70. ubiegłego wieku metropolie rozwijają się jako struktury "pozamiejskie” (ex-urban areas), obejmujące całość obszarów powiązanych $\mathrm{w}$ układ metropolitalny, niekoniecznie zdominowany przez centrum (Kozielska 2008; Staszewska 2012: 53-68). Zmiany, jakie zachodzą w układach przestrzennych metropolii, trudno jest łączyć z klasycznymi ujęciami modelu miasta przemysłowego (tzw. szkoła chicagowska; Walker 1981: 383-429). W takim ujęciu rozproszone struktury metropolii są w coraz mniejszym stopniu monocentryczne i coraz rzadziej można opisać je w kategoriach wyłącznie miejskich, podmiejskich oraz miejskim lub nie miejskim stylem życia (Węcławowicz 2003; Scott i in. 2001: 11-30).

Współczesne procesy urbanizacji, obejmujące rozległe obszary poza formalnym zasięgiem miast, charakteryzują się często równoczesną dekoncentracją i powtórną koncentracją ludności oraz aktywności gospodarczej i społecznej, co prowadzi do powstawania wieloośrodkowych regionów metropolitalnych. Takie układy przestrzenne wyróżniają się występowaniem kilku typowych cech:

- zwykle kilka różnej rangi ośrodków centralnych (central city); są to najczęściej historyczne centra w regionie, natomiast współcześnie ich funkcje przejęły inne zurbanizowane miejsca;

- skomplikowane przemieszanie obszarów o niskiej (zabudowa typu urban sprawl) i wysokiej gęstości zaludnienia oraz przestrzenna dywersyfikacja miejsc pracy, przestrzeni biurowych i handlowych oraz funkcji kultury w skali regionu; 
- kreacja licznych, konkurujących centrów polityki lokalnej;

- rosnąca dominacja układu komunikacyjno-transportowego i logistycznego w strukturze przestrzennej i społeczno-gospodarczej (specjalizacja przestrzenna) połączona z niewspółmiernym wzrostem infrastruktury (autostrady, drogi, obwodnice, stacje obsługi, lotnisko i jego zaplecze, wewnętrzne systemy transportu itd.), której węzły stopniowo odbieraja funkcje dawnemu centrum (Gottdiener, Kephart 1991: 31-54; Gottdiener, Hutchison 1999).

W efekcie tych procesów różne typy zabudowy (o charakterze wytwórczym - wytwórnie, fabryki, magazyny i składy, usługowym - banki, usługi doradcze, firmy ubezpieczeniowe, hotele i handlowym - hurtownie, handel wielkopowierzchniowy, detaliczny, restauracje, warsztaty naprawcze itd.), żywiołowo powstają w całym regionie miejskim. Lokalizacja w strefie zewnętrznej aglomeracji miejskich typowo miejskich aktywności i form działalności odzwierciedla zarówno dekoncentrację (aktywności i działalności o swobodnym i uzależnionym od kosztów umiejscowieniu), jak koncentrację (instytucje i działania związane $\mathrm{z}$ hierarchią wyboru lokalizacji z poziomu międzynarodowego, krajowego lub regionalnego), stając się nową charakterystyczną formą procesu suburbanizacji.

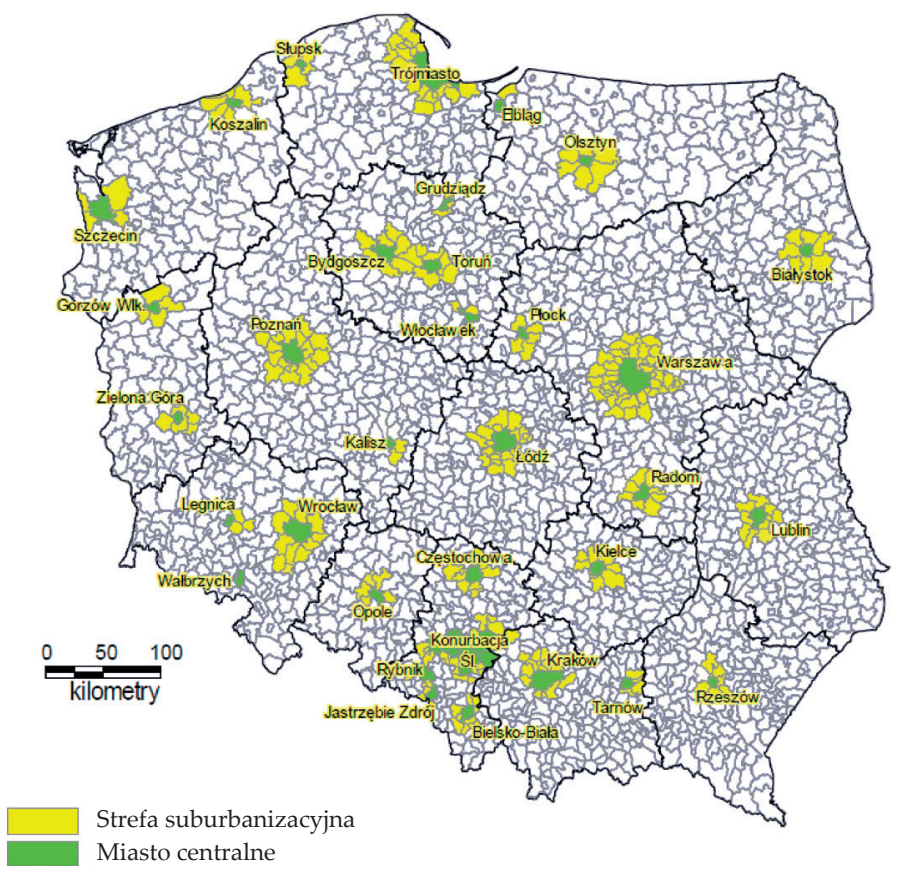

Ryc. 1. Strefy suburbanizacji wokół miast powyżej 90 tys. mieszkańców Źródło: (Celińska-Janowicz 2010). 
Powstające formy przestrzenne, niekoniecznie związane $\mathrm{z}$ tradycyjną dla procesu suburbanizacji dominacją relatywnie ekstensywnej funkcji mieszkaniowej, nadają stopniowo regionowi metropolitalnemu policentrycznego charakteru. Masowy charakter procesu dekoncentracji oraz jego skutki w zagospodarowaniu przestrzennym pogłębiają i przyspieszają urbanizację zewnętrznej strefy miast. Biorąc pod uwagę głębokość, intensywność i kierunek zmian, dokonujących się pod wpływem rozwijających się miast, czyli relację między obszarami miejskimi i wsią w ich otoczeniu - obszary wiejskie dzieli się na zintegrowane (integrated rural areas), pośrednie (intermediate rural areas) i peryferyjne (remote rural areas); por. Wilkin 2007; Rakowska, Wojewódzka-Wiewiórska 2010.

Oddziaływanie miast na otoczenie wiejskie ma charakter strefowy i ulega osłabieniu w miarę oddalania się od centrum miejskiego, jednak rozprzestrzenianie się zjawisk urbanizacyjnych obejmuje nie tylko bezpośrednie otoczenie miast, lecz także strefę pośrednią, a $\mathrm{w}$ rejonach peryferyjnych przyspiesza i pogłębia zjawiska negatywne. $W$ takim kontekście strefowy układ oddziaływania miast nie stanowi wystarczająco mocnej podstawy dla modelu rozwoju opartego na koniunkcji możliwości rozwoju terenów wiejskich z siłą związków z ośrodkami metropolitalnymi. Jak się ocenia, jest to strategia szczególnie niebezpieczna tam, gdzie sieć ośrodków o cechach metropolitalnych jest rzadka lub tereny wiejskie znajdują się w strefach wpływów miast typu regionalnego, a więc bez możliwości tworzenia układów wieloośrodkowych.

\section{Skala procesu suburbanizacji w Polsce}

Zjawiska suburbanizacyjne występują praktycznie we wszystkich strefach podmiejskich większych miast w Polsce (analogicznie do procesów w miastach europejskich). Największa ich intensywność charakteryzuje gminy wiejskie, bezpośrednio sąsiadujące $\mathrm{z}$ miastami centralnymi oraz tereny wzdłuż głównych tras komunikacyjnych (Reckien, Karecha 2007: 39-67).

Badania nad wybranymi miastami w Polsce (32 ośrodki) wykazały, że w latach 2005-2008 ich populacja zmniejszyła się o 0,8\%, natomiast w ich strefach suburbanizacji zwiększyła się o $4 \%$. W największym stopniu proces objął obszary miejskie Łodzi, Poznania, Katowic i Bydgoszczy, ale pośród najszybciej wyludniających się znalazły się liczne miasta aglomeracji górnośląskiej - Sosnowiec, Bytom, Gliwice i Ruda Śląska oraz Częstochowa. Natomiast żadna z gmin w ich strefach suburbanizacji nie znalazła się w grupie jednostek o największym wzroście zaludnienia. W tym samym czasie średnie saldo migracji w strefach suburbanizacji osiągnęło 
poziom $4,8 \%$, a w miastach centralnych wskaźnik zyskał wartość ujemną $(-0,7 \%)$. W porównaniu z pierwszą połową XXI w. natężenie procesu suburbanizacji w otoczeniu miast (mierzone saldem migracji) wzrosło, najsilniej w największych ośrodkach miejskich (metropolie i główne centra regionalne); por. Węcławowicz i in. 2010.

Saldo migracji jest odwrotnie proporcjonalne do wielkości i znaczenia miast - im ośrodek miejski niżej położony w hierarchii ośrodków krajowych (Celińska-Janowicz i in. 2010), tym większa skala odpływu mieszkańców z centrum, ale równocześnie mniejsze dodatnie saldo migracji w strefach suburbanizacji. Oznacza to odpływ ludności głównie do innych, większych centrów miejskich. Najwyższe natężenie przepływu do stref podmiejskich głównych ośrodków regionalnych charakteryzuje miasta metropolitalne i niektóre centra regionalne. Wśród tych pierwszych najwyższe dodatnie salda migracji w strefach suburbanizacji występowały w strefie Poznania $(8,8 \%)$, zaś najniższe - w strefie konurbacji śląskiej $(1,8 \%)$ i Łodzi (2,5\%, w latach 2005-2008). Zmiany zachodzące w obszarach miejskich wskazują przede wszystkim na skomplikowaną naturę procesu suburbanizacji w dużych metropoliach, gdzie rozwój przestrzenny jest integralnie połączony z głębokimi przeobrażeniami restrukturyzacyjnymi w sferze gospodarczej i społeczno-kulturowej.

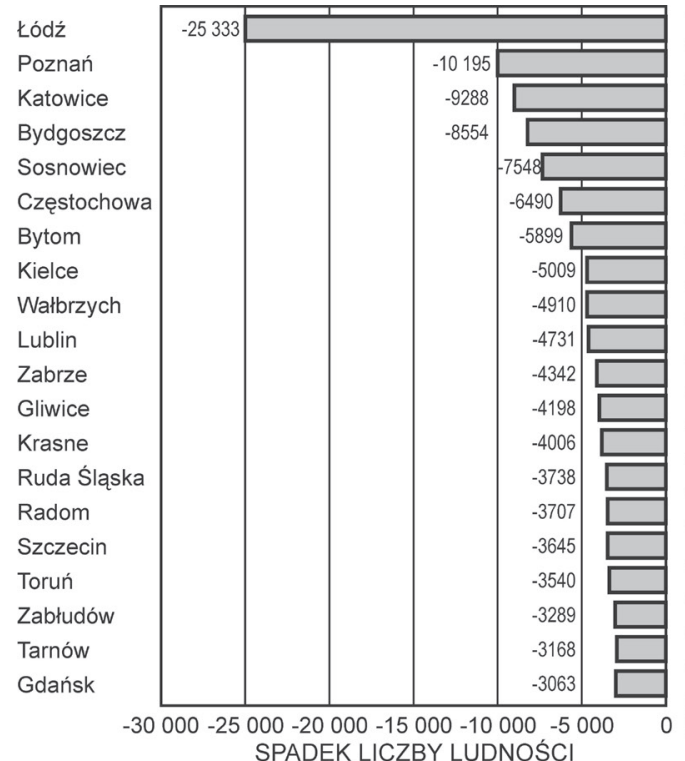

A

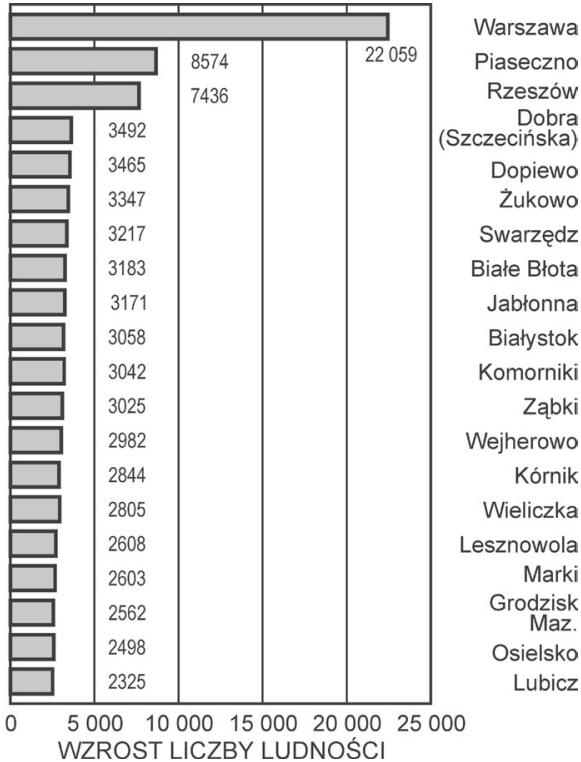

$\mathrm{B}$

Ryc. 2. Miasta i gminy o największym spadku (A) i wzroście (B) liczby ludności w latach 2003-2007 Źródło: (Węcławowicz i in. 2010) 
Wśród ośrodków metropolitalnych tylko Warszawę cechuje znaczące, dodatnie saldo migracji $(1,5 \%)$ przy mniejszym natężeniu napływu w strefie suburbanizacji (5,3\%). Niewielki, dodatni bilans migracyjny charakteryzował także Gdańsk i Wrocław. Generalnie, zarówno ośrodki regionalne (np. Lublin, Szczecin, Toruń, Kielce, Zielona Góra), jak i subregionalne (Częstochowa, Płock, Kalisz, Tarnów, Grudziądz), a nawet niektóre ośrodki ponadlokalne cechowały się wyraźną przewagą napływu nad odpływem w ujęciu całych obszarów miejskich. Najniższe wśród wszystkich 32 badanych miast (1\%) saldo migracji miał Rybnik, co wyjaśniano charakterystycznym dla tej części województwa śląskiego brakiem istotnego zróżnicowania układu miejskiego i podmiejskiego pod względem struktury przestrzennej i gospodarczej (specyfika zjawiska suburbanizacji). Tu, przesunięcie do strefy podmiejskiej praktycznie nie oznacza dla mieszkańców miasta istotnej zmiany otoczenia, natomiast jednym z głównych powodów migracji ludności do stref podmiejskich jest chęć poprawy warunków życia, zarówno w sensie przestrzennym, jak i w aspekcie ekologicznym. Autorzy badania uważają że niskie saldo migracji jest w tej sytuacji skutkiem występowania stosunkowo dużej powierzchni i relatywnie niskiej gęstości zaludnienia (ok. 950 osób/km²), monofunkcyjnej gospodarki miejskiej, opartej na tradycyjnym górnictwie węgla kamiennego i energetyce, deprecjonującej środowisko naturalne otaczających obszarów. W mojej opinii przyczyny tkwią w stopniowym wyczerpaniu potencjału miasta do migracji i w nasyceniu otoczenia miasta obszarami w pełni zurbanizowanymi (definitywna suburbanizacja); por. Krzysztofik 2007; Budziński i in. 2014. Procesy suburbanizacji łączą się też z wyraźnym przyrostem najmłodszej i najstarszej grupy wiekowej w otoczeniu wiejskim dużych ośrodków miejskich. Migrują przeważnie osoby w wieku prokreacyjnym, które przeprowadzkę pod miasto wiążą z założeniem rodziny i posiadaniem dzieci.

Stałym procesem, obserwowanym zarówno w latach 2002-2005, jak i w okresie 2005-2008, był znaczący wzrost populacji w wieku powyżej 70 lat, przy czym jedynie w przypadku ośrodków metropolitalnych wzrost $\mathrm{w}$ strefach suburbanizacji nieznacznie przewyższał przyrost odnotowywany $\mathrm{w}$ mieście centralnym. Jest to skutek ogólniejszych procesów starzenia się populacji, które obejmują całe obszary miejskie i prowadzą do wzrostu zapotrzebowania na różnego typu usługi publiczne (opieka nad niemowlętami, ośrodki lekarskie, przedszkola, a później edukacja w zakresie szkolnictwa podstawowego i gimnazjalnego). Przyrosty liczby ludności w najstarszych kategoriach wiekowych, zwykle o ograniczonej mobilności - zarówno w miastach centralnych, jak i ich strefach suburbanizacji - można łączyć z intensyfikacją zapotrzebowania na usługi związane z opieką społeczną i podstawową opieką medyczną. 
Generalnie, prognozowane wcześniej przyspieszenie procesu urbanizacji w pierwszej dekadzie XXI w. jako jednego ze skutków transformacji społeczno-gospodarczej w latach 90. - pomimo wchodzenia na rynek pracy osób z wyżu demograficznego z początku lat 80. ubiegłego wieku - nie nastąpiło (Sytuacja demograficzna... 2004; procesy urbanizacyjne w Polsce załamały się na dużo niższym poziomie formalnego udziału ludności miejskiej w ogólnej liczbie mieszkańców niż w innych krajach europejskich - ok. $60 \%$ w Polsce, gdy w Europie zachodniej ok. $80 \%$ ). Nie wzrastają same miasta centralne (poza nielicznymi wyjątkami), ale całe obszary metropolitalne (obszary miejskie), co świadczy o nasilaniu się zjawiska suburbanizacji. Zwiększa się więc obszar oddziaływania największych ośrodków miejskich, ale nie rośnie potencjał ludnościowy ich centrów, co oznacza relatywnie słabsze wpływy i powiązania z otaczającymi obszarami wiejskimi. Również inne badania wskazują że ujemne salda migracji obszarów centralnych dużych i średnich miast są sumarycznym efektem suburbanizacji, a ich wiejskie otoczenie często cechuje znaczne, dodatnie saldo migracji (Sobala-Gwosdz [red.] 2010). W województwie śląskim taki układ jest charakterystyczny dla Bielska-Białej, Częstochowy, Żywca, Cieszyna, Raciborza, Rybnika i Lublińca, a w mniejszym stopniu dla Gliwic i Kłobucka. Ogólnie biorąc, łączny bilans zmian ludnościowych w obszarach miejskich (miasto i otaczające gminy wiejskie) jest dodatni, nie zmniejsza się również znacząco potencjał gospodarczy miasta, gdyż większość potrzeb mieszkańcy terenów podmiejskich nadal zaspokajają w śródmieściu lub miejskich centrach handlowo-usługowych. Stopniowy transfer klasy średniej do gmin wiejskich otaczających miasta pociagga za sobą liczne negatywne konsekwencje dla funkcjonowania samych miast (m.in. zmniejszanie się lokalnej bazy podatkowej, powstawanie dzielnic problemowych, gorsze warunki funkcjonowania transportu miejskiego).

\section{Wpływ procesu suburbanizacji na zagospodarowanie przestrzenne}

W ujęciu teoretycznym proces suburbanizacji interpretowany jest zwykle jako etap, forma lub faza zjawiska urbanizacji, związana z przenoszeniem się mieszkańców miast wraz z ich stylem życia, formami krajobrazowymi i użytkowaniem ziemi, infrastrukturą miejską i miejscami pracy na otaczające miasto obszary wiejskie.

Suburbanizacja - jako proces zagospodarowania przestrzennego - jest traktowana jako niekorzystne gospodarczo i społecznie zjawisko rozprzestrzenienia się struktury miejskiej na obszary zewnętrzne, często na tereny otwarte, a także przyrodniczo cenne. $W$ opinii środowisk 
urbanistyczno-planistycznych i socjologicznych prowadzi to do nadmiernej, niekontrolowanej urbanizacji jednostek osadnictwa wiejskiego, znajdujących się w strefie określonej dogodną dostępnością komunikacyjną, a przede wszystkim korzystną podażą nieruchomości. Chaotyczny charakter tego procesu i pogłębiający się brak ładu przestrzennego w skali lokalnej i regionalnej wpływa na degradację wartości krajobrazu wiejskiego, utratę tożsamości kulturowej i wzrost zróżnicowania społecznego, a także skutkuje spadkiem kapitału społecznego (Czernik 2007: 317-332; Zathey 2004: 94-106). W takim sensie sam proces suburbanizacji i jego skutki są nazywane urban sprawl (rozprzestrzenianiem się miasta).

Proces suburbanizacji $\mathrm{w}$ sensie przestrzennym charakteryzują trzy główne cechy obszarów wiejskich, w strefach oddziaływania i powiązań z miastem, gdzie dokonuje się ekspansja zabudowy miejskiej (urban sprawl):

- luźna forma zabudowy mieszkaniowej (brak zwartości zabudowy); tereny ekspansji budownictwa mieszkaniowego na obrzeżach miast cechują się stosunkową niską gęstością zabudowy, a co za tym idzie również gęstością zaludnienia. Aglomeracje miast amerykańskich należą do tych, które cechują się najniższą gęstością zabudowy spośród wszystkich obszarów miejskich na świecie (por. Kozielska 2008; Czerny 2005). Tereny budownictwa inspirowanego związkami z pobliskim miastem charakteryzują się również niskim poziomem koncentracji różnego typu obiektów o funkcjach usługowych. Zabudowa jest niska - parterowa lub jednopiętrowa, bez wyraźnego układu centrum. Obszary suburbanizacji (szczególnie na tzw. surowym korzeniu) z natury rzeczy stają się monofunkcyjne, mieszkaniowe;

- brak ciągłości zabudowy osiedli mieszkaniowych na terenach rolniczych - obszary zurbanizowane występują na przemian z rolniczymi lub leśnymi, nie tworząc zwartych struktur przypominających układ miejski;

- segregacja funkcjonalna lub homogeniczność zabudowy podmiejskiej (urban sprawl), która poprzez powtarzalność elementów składowych (rzędy jednakowych lub bardzo podobnych jednorodzinnych domów, z trawnikami i garażami, kwartały rozdzielone szerokimi pasmami ulic) i mieszkaniową monofunkcyjność, a także separację od innych funkcji miejskich (tereny przemysłowe, ciągi lub centra handlowo-usługowe), czyni tego typu struktury całkowicie uzależnionymi od procesów zewnętrznych (Kaplan i in. 2004).

Postępujący proces suburbanizacji, polegający na niekontrolowanym rozlewaniu się zabudowy związanej z miastem na tereny wiejskie, generuje nadmierne dojazdy do pracy, a poprzez wkraczanie na tereny otwarte stwarza rosnące zagrożenia środowiskowe oraz strukturalne problemy 
w planowaniu przestrzennym. Żywiołowa suburbanizacja (urban sprawl) skutkuje różnego typu negatywnymi zjawiskami ocenianymi zwykle w trzech aspektach: środowiskowym, ekonomiczno-przestrzennym i społecznym (tab. 1).

Tabela 1. Typowe skutki procesu żywiołowej suburbanizacji oraz ich aspekty

\begin{tabular}{|c|c|c|}
\hline Aspekt środowiskowy & $\begin{array}{c}\text { Aspekt } \\
\text { ekonomiczno-przestrzenny }\end{array}$ & Aspekt społeczny \\
\hline $\begin{array}{l}\text { - zmniejszanie się terenów rol- } \\
\text { nych i leśnych, czynnych eko- } \\
\text { logicznie; } \\
\text { - wzrost zanieczyszczenia śro- } \\
\text { dowiska spalinami; } \\
\text { - bezpośrednia lub pośrednia } \\
\text { degradacja terenów cennych } \\
\text { przyrodniczo } \\
\text { - wzrost powierzchni perma- } \\
\text { nentnie penetrowanej przez } \\
\text { ludzi }\end{array}$ & $\begin{array}{l}\text { - brak ładu przestrzennego } \\
\text { i estetyki krajobrazu; } \\
\text { - brak przestrzeni publicznych } \\
\text { na nowo zurbanizowanych te- } \\
\text { renach; } \\
\text { - zmniejszanie znaczenia ob- } \\
\text { szarów centralnych miast; } \\
\text { - zwiększenie kosztów budo- } \\
\text { wy i utrzymania infrastruktury; } \\
\text { - wydłużenie czasu dojazdu } \\
\text { do pracy; } \\
\text { - nadmierna eksploatacja dróg } \\
\text { kołowych }\end{array}$ & $\begin{array}{l}\text { - socjalna segregacja ludności } \\
\text { (w centrach miast zamieszku- } \\
\text { je najuboższa ludność, a na } \\
\text { przedmieściach najbogatsza), } \\
\text { - osłabienie więzi społecznych } \\
\text { i postawy antyspołeczne na su- } \\
\text { burbiach, } \\
\text { - problemy społeczne wynika- } \\
\text { jące z braku odpowiedniej in- } \\
\text { frastruktury technicznej i spo- } \\
\text { łecznej }\end{array}$ \\
\hline
\end{tabular}

Źródło: opracowanie własne na podstawie (Mielczarek 2011).

Wśród badaczy zjawiska urban sprawl zdecydowanie przeważają ci, którzy negatywnie oceniają ten proces (Jackson 1985; Lisowski 2005a: 91-100). Wprawdzie zwolennicy takich przeobrażeń przestrzennych kontrargumentują twierdząc, że współczesne rolnictwo nie potrzebuje tak rozległych terenów, w wielkich blokowiskach miejskich i tak trudno o utrzymanie więzi społecznych, a korzystanie z transportu zbiorowego $\mathrm{w}$ miastach jest uciążliwe i nieefektywne. Wiele niekorzystnych skutków związanych z urban sprawl można uznać za konsekwencję coraz powszechniej panującego, miejskiego stylu życia. Wprawdzie trudno ocenić jednoznacznie jego środowiskowe, społeczne i ekonomiczne koszty, ale liczba zidentyfikowanych „niekorzyści” skłania do jego ograniczania i przeciwdziałania mu. Niejednoznaczne są także prognozy rozwoju zjawiska w dłuższej perspektywie i dalszych skutków niekontrolowanego przyrostu zabudowy poza obszarem miejskim (Litwińska 2008: 42-43).

Zdecydowanie negatywna ocena procesów żywiołowej suburbanizacji w środowiskach naukowych i wśród praktyków sterowania procesami zagospodarowania przestrzennego prowadzi do formułowania postulatów rozwoju miast (aglomeracji miejskich) w formach, które nie wywołują przyrostu ich struktury w obszarach zewnętrznych, wskazując na możliwości tworzenia suburbiów wewnątrzmiejskich (Rusk 1995). W prostej 
linii są to koncepcje polegające na dążeniu do intensyfikacji i pełniejszego wykorzystania terenów otwartych, restrukturyzowanych, zdewastowanych, areałów typu brownfields - $\mathrm{w}$ dotychczasowym zasięgu miast, a w szczególności w strefach ograniczonych zasięgiem obszarów w pełni zurbanizowanych.

Poza funkcjami mieszkaniowymi strefa suburbanizacji (podmiejska) przejmuje w coraz większym stopniu funkcje przemysłowo-produkcyjne, magazynowo-logistyczne i usługowo-handlowe, a także rekreacyjno-rozrywkowe. Kwestia wyważenia tych funkcji i struktur zainwestowania jest zagadnieniem priorytetowym dla strategii rozwoju, działań planistycznych i decyzyjnych samorządów lokalnych. Nie ulega wątpliwości, że proces suburbanizacji jest pochodną głębokich i gwałtownych zmian w sferze konsumpcji, gdzie realizowane są potrzeby obecnych i przyszłych generacji. Wzrost poziomu i jakości życia w aspekcie zrównoważonego rozwoju skutkuje zmianami preferencji konsumentów w zakresie stylu zamieszkania (zabudowa wysoka czy niska, luźna czy zwarta), typu transportu (prywatny czy publiczny), świadomości ekologicznej (recykling czy tradycyjne odprowadzanie odpadów). Zespół uwarunkowań społeczno-ekonomicznych i kulturowych kształtuje strukturę napływu mieszkańców miast do strefy obszarów wiejskich w ich otoczeniu, co skutkuje wzrostem popytu na wolną przestrzeń oraz jej żywiołowym zagospodarowaniem (Ouřednicek, Posova 2006: 96-113).

Proces suburbanizacji, ze względu na głębokie przekształcenia wsi w zewnętrznej przestrzeni miast, w ich strukturze społeczno-gospodarczej i w środowisku przyrodniczym, również w kręgach urbanistów, ekologów, socjologów wsi i ekonomistów najczęściej jest oceniany jako zjawisko co najmniej niekorzystne (Lisowski 2005b: 83-99; Aguilera, Mignot 2004: 93-113; Kamiński 2005: 95-101). Dokonująca się pod wpływem rozwoju miast transformacja obszarów wiejskich wiąże się również z aspektami odczuwanymi jako korzystne, dostrzeganymi zarówno przez lokalne społeczności wiejskie, jak i władze samorządowe, zwłaszcza w początkowym stadium tego procesu. Pozytywne aspekty suburbanizacji, pomijane lub marginalizowane ( $\mathrm{w}$ świetle generalnie negatywnych ocen procesu żywiołowej urbanizacji) stanowią najczęściej uzasadnienie do masowych decyzji planistycznych, podejmowanych przez samorządy lokalne. Przede wszystkim chodzi o nieskrępowane przeznaczanie gruntów pod lokalizację różnego rodzaju inwestycji, które skutkują żywiołowym zagospodarowaniem rozległych obszarów dotąd użytkowanych rolniczo lub stanowiących użytki ekologiczne. Dostrzeganie bieżących korzyści wynikających $\mathrm{z}$ tego procesu jest nie tylko istotne dla zidentyfikowania jego genezy, lecz także ważne dla przygotowania strategii transformacji obszarów wiejskich w strefie oddziaływania miasta (Zimnicka, Czernik 2007; Zimnicka 2006). 
Jeśli odwołać się do przykładu koncepcji rozwoju przestrzennego związanego z przebiegiem procesu suburbanizacji wybranych wsi w strefie oddziaływania Londynu, to jej kształtowanie opiera się na restrykcyjnie przestrzeganych zasadach zachowania ładu przestrzennego, kontynuacji ciągłości kulturowej, zrównoważonego rozwoju, wynikających z przyjmowanych przez lokalne władze założeń planów strukturalnych i miejscowych (Czernik 2007: 317-332). W dużym uproszczeniu, głównym kierunkiem dopuszczonych działań jest zachowanie tożsamości wsi w aspekcie rewaloryzacji zabudowy historycznej i utrzymania cech integralności formy przestrzennej, uniemożliwiającej niekontrolowane formy rozproszenia zainwestowania mieszkaniowego i innego. Istotne jest też kształtowanie systemu przestrzeni publicznych oraz utrzymanie i wprowadzenie kompleksów zieleni, scalających układ przestrzenny miejscowości.

Zwraca się uwagę na aktywizację gospodarczą, zwłaszcza w zakresie utrzymania zanikającej funkcji rolniczej, bowiem jej podtrzymywanie, nawet $\mathrm{w}$ bezpośrednim otoczeniu miasta, przyczynia się do przywracania tradycyjnych, ale zanikających form lokalnego zatrudnienia oraz odbudowywania więzi społecznych mieszkańców (Czernik 2007). W powoływanym przykładzie chodzi o wieś Marden i podtrzymywanie sadownictwa. Zarządzanie i kontrola realizowana przez samorząd lokalny opiera się na miejscowym akcie prawa (miejscowy plan zagospodarowania przestrzennego), na dużej partycypacji społecznej i zaangażowaniu i funkcjonuje dzięki ukonstytuowanym formom organizacji społecznych (Czernik 2008).

\section{Suburbanizacja jako wyzwanie - nowe funkcje obszarów wiejskich $w$ warunkach regionów zurbanizowanych i regionów metropolizujących się}

W niektórych pracach sugeruje się, że potencjał przyciagania nowych mieszkańców przez obrzeża miasta (zwłaszcza wielkiego) musi się po pewnym czasie wyczerpać, tak ze względów infrastrukturalnych (np. wskutek narastania niewydolności układów komunikacyjnych, infrastrukturalnych), jak i ekonomicznych (m.in. wzrastająca dostępność i atrakcyjność inwestycyjna zdegradowanych lub ekstensywnie wykorzystywanych terenów śródmiejskich) - por. Parteka 2005. W większości polskich aglomeracji miejskich aż do końca pierwszej dekady XXI w. nie było jednak widocznych oznak spadku dynamiki procesów suburbanizacyjnych. Wręcz przeciwnie - pojawiają się nowe narzędzia inwestowania w nieruchomości w strefach podmiejskich największych miast (fundusze inwestycyjne). Dodatkowo, złożoność procesów inwestowania w dużych 
miastach ogranicza liczbę takich projektów, choć oczywiście są przykłady udanych działań w tym zakresie, jakkolwiek ich rentowość jest ograniczona (m.in. kompleks mieszkaniowy Tytoniówka w Białymstoku, tereny dawnych Państwowych Zakładów Optycznych w Warszawie, kompleks usługowo-mieszkaniowy Silesia-Dębowe Tarasy w Katowicach).

Skutki regresu demograficznego, stopniowo ujawniające się w większych miastach Polski, to połączenie konsekwencji suburbanizacji z negatywnymi efektami spadku populacji miast, wynikającego z rosnących migracji wewnętrznych i zewnętrznych (konkurencja innych miast, w tym europejskich) oraz naturalnych procesów demograficznych. Należą do nich postępująca segregacja przestrzenna mieszkańców, malejące gwałtownie znaczenie dzielnic śródmiejskich, degradacja przestrzenna obszarów podmiejskich (rosnące zagęszczenie zabudowy, wzrost zanieczyszczenia środowiska przyrodniczego, niewydolność infrastruktury komunalnej i transportowej, niedobór usług i handlu), ograniczenie bazy ekonomicznej miasta i malejące wpływy z podatków, przesuwające się do urbanizujących się gmin ościennyc, przeciążenie infrastruktury transportowej oraz postępujące zmniejszanie gęstości zaludnienia.

Specyficznymi "produktami” suburbanizacji są - powstające w wiejskim otoczeniu dużych ośrodków miejskich - osiedla podmiejskie. Dopiero po uwzględnieniu złożonych charakterystyk miejsc poddawanych presji miejskiej oraz cech społeczno-demograficznych nowych osadników można wyjaśnić problemy (konflikty) przestrzenne i społeczne, narastające w strefach intensywnej suburbanizacji. Wprawdzie przynajmniej część byłych mieszkańców miast nadal pozostaje w określonej relacji z dawnym miejscem zamieszkania (praca, korzystanie z wszelkiej infrastruktury miejskiej, asekuracyjne utrzymywanie mieszkania w mieście, zasilanie pozostałej rodziny środkami finansowymi i in.), co w pewnym stopniu podtrzymuje ekonomiczne oddziaływanie na centra miejskie. Jednak efekty depopulacji demograficznej (ujemny przyrost naturalny, ujemne saldo migracji zewnętrznych z innymi miastami) trudno odwrócić lub zrekompensować (Czarnecki 2011).

Wśród charakterystycznych cech, wyróżniających obszary intensywnej i żywiołowej suburbanizacji wsi (układy przestrzenne typu suburbia), niezależnie od lokalizacji w strefie oddziaływania ośrodka miejskiego, wymienia się najczęściej:

- umiejscowienie na obszarach wiejskich, poza granicami administracyjnymi miasta centralnego (obszar wiejski rozumiany jest jako gmina wiejska lub miejsko-wiejska o populacji miasta nie przekraczającej 20 tys. mieszkańców albo miasto o takiej populacji w otoczeniu gmin wiejskich i wiejsko-miejskich; więcej np. definicja obszarów wiejskich przyjęta w ZPORR); 
- stosunkowo duża odległość od centrum miasta, z którym są powiązane (czas dojazdu);

- całkowicie miejski, nie związany z rolnictwem, charakter osadnictwa;

- dominująca funkcja mieszkaniowa;

- przewaga ekstensywnej zabudowy jednorodzinnej;

- autonomia administracyjna, duża niezależność lokalnych samorządów w układzie aglomeracyjnym;

- dobra, ale czasochłonna dostępność do rynku pracy w centrum;

- społeczna homogeniczność i powiązanie z etapami tzw. cyklu rodzinnego;

- silny napływ ludności z centralnych dzielnic miasta (Kozielska 2008).

Charakterystyczną cechą procesu suburbanizacji jest też znacznie szybszy rozwój mieszkalnictwa w stosunku do przyrostu miejsc pracy i usług. Powstawanie w otoczeniu wielkich miast monofunkcyjnych obszarów mieszkalnictwa jednorodzinnego powoduje silne uzależnienie od transportu indywidualnego, który generuje problemy transportowe oraz narastające konflikty przestrzenne i planistyczne. Nie jest to problem nowy. Równocześnie trzeba jednak wyraźnie podkreślić, że procesy suburbanizacji $\mathrm{w}$ otoczeniu polskich miast tylko częściowo przebiegają 92 analogicznie do zjawisk obserwowanych w aglomeracjach miejskich Europy zachodniej czy USA. Dodatkowo, definitywnie podmiejski charakter przestrzeni powstających poza miastem wyłania się w efekcie stosowania przez mieszkańców suburbiów społecznych praktyk naznaczających przestrzeń, a nakierowanych na dopasowanie jej cech do ich specyficznych potrzeb. Spośród wielu różnic, cechami odróżniającymi suburbia zachodnie od polskich są kwestie lokalizacyjne (czynnik odległości od centrum miasta odgrywa w Polsce kluczową rolę) i administracyjna niezależność przedmieść stanowiących formalnie część obszarów wiejskich.

Pierwsza różnica (odległość od centrum) wymaga większej liczby wolnych i dostępnych nieruchomości, jest też konsekwencją społecznych dążeń do zasiedlania większych działek i możliwości, by te dążenia zaspokajać. Druga różnica (niezależność administracyjna) to efekt specyficznego rozwoju współczesnych polskich osiedli podmiejskich, które najczęściej powstają jako zwarte kompleksy zabudowy lub rozproszone budownictwo o miejskim charakterze $\mathrm{w}$ pobliżu już istniejących siedlisk wiejskich. Jeśli w okresie socjalistycznym, w miarę rozwoju miasta, tereny podmiejskie były stopniowo włączane do miejskiego obszaru administracyjnego i zagospodarowywane uspołecznionym budownictwem masowym (wielorodzinne), które miało zaspokoić głód mieszkaniowy (Kajdanek 2011) - to po roku 1990 tego typu praktyki są rzadkością i nawet $\mathrm{w}$ pełni zurbanizowane gminy wiejskie bronią się przed włączeniem 
w strukturę administracyjną miasta i starają się utrzymać formalną niezależność (Heffner, Gibas 2014).

Chociaż istnieją różne typy suburbiów, dobra dostępność do pracy w centrum (najczęściej wynikająca z lokowania nowych osiedli główne wzdłuż dawnych dróg - tzw. obudowa szlaków komunikacyjnych) i dominacja zabudowy mieszkaniowej typu jednorodzinnego (często przy współobecności zabudowy wielorodzinnej) są ich charakterystycznymi cechami. Również homogeniczność i powiązanie zamieszkiwania w suburbiach z zaawansowanym etapem cyklu rodzinnego dołączają się do zespołu cech charakterystycznych suburbanizacji w Polsce.

Począwszy od wejścia w fazę transformacji (lata 90.), praktycznie nigdzie w Polsce nie realizuje się koncepcji tzw. miasta zwartego (compact city), a procesy rewitalizacji centrów miast prowadzone są wolno i w zbyt małej skali, by mogły stanowić realną przeciwwagę wobec rozlewania się miast. Wszystko to świadczy o długotrwałym i głębokim kryzysie planowania przestrzennego, zwłaszcza miejscowego, przede wszystkim w odniesieniu do przestrzeni zurbanizowanych. Proces suburbanizacji w Polsce - ze względu na relatywnie krótki okres rozwoju oraz selektywność oddziaływania, a także szczególne cechy, związane z ekstensywną obudową typowo miejskimi domami jednorodzinnymi pierwotnych układów morfologicznych wsi (często średniowiecznych i słabo zmienionych strukturalnie ze względu na podtrzymywaną aż po lata 90. dominującą funkcję rolniczą) oraz dużą dynamikę przyrostu nowej zabudowy - stał się jednym z najważniejszych czynników przekształceń obszarów wiejskich i podmiejskich. Częstym problemem, który pojawił się w związku z masowością i tempem procesu suburbanizacji jest brak formalnego powiązania (zameldowanie w nowym miejscu pobytu) nowych osadników ze społecznościami i strukturami lokalnie zintegrowanych starych wsi, na których terenach (użytkach) osiedlili się. Generuje to poważne konflikty funkcjonalne w strefie suburbanizacji:

- duże (i najczęściej niezaspokojone) oczekiwania dotyczące infrastruktury technicznej i społecznej;

- niskie zaangażowanie w życie społeczne i polityczne pierwotnej części wsi (negacja tradycyjnych organizacji wiejskich i brak zaangażowania w nowe organizacje pozarządowe powstające na wsiach);

- wycofanie się z korzystania z usług świadczonych na wsi, zwłaszcza edukacji dzieci, zakupów codziennych i drobnych usług osobistych;

- kreowanie luki finansowej, która tworzy się w gminnych budżetach z powodu braku formalnego zameldowania na wsi (Kajdanek 2011).

Na poziomie centralnym zidentyfikowano cztery pola, gdzie polityka spójności, poprzez realizację odpowiednich projektów, może niwelować lub zapobiegać negatywnym skutkom procesu suburbanizacji. Są to: 
- planowanie przestrzenne (miejscowe plany zagospodarowania przestrzennego o bardziej kompleksowych charakterze, zaniechanie segmentacji i atomizacji przestrzeni podmiejskiej);

- inwestycje w infrastrukturę transportową (dywersyfikacja w zakresie transportu publicznego i odejście od preferencji dla transportu indywidualnego);

- podstawowa infrastruktura społeczna (podtrzymywanie kluczowych usług zdrowotnych, edukacyjnych i kulturalnych) oraz środowiskowa (wodno-kanalizacyjna, związana z gospodarką odpadami).

Badania typu ewaluacyjnego, dotyczące wpływu polityki spójności (okres 2004-2006) na zmniejszenie negatywnych skutków suburbanizacji w otoczeniu większych polskich miast (powyżej 90 tys. mieszkańców) w opinii autorów umożliwiły określenie rzeczywistego zakresu tego zjawiska (Celińska-Janowicz i in. 2010; oparto się na analizie przyrostów liczby ludności w dwóch okresach 2002-2005 i 2005-2008 oraz saldzie migracji - powyżej 3\%, badaniach ankietowych i wywiadach z beneficjentami projektów; dodatkowo, w wyniku analizy kartograficznej, wytypowano gminy tworzące zwarte strefy suburbanizacji wokół wybranych miast). Wykorzystując studia przypadków, podjęto także próbę określenia wpływu zrealizowanych projektów kohezyjnych z lat 20042006 na skutki procesów suburbanizacyjnych (analizy objęły 4 przypadki w strefie Warszawy, 3 - Poznania, 2 - Lublina oraz po $1 \mathrm{w}$ strefach Zielonej Góry i Rybnika). Miasta w Polsce - mimo tego, że są głównymi centrami rozwojowymi - borykają się z problemami niesprawnego układu transportowego, niską jakością przestrzeni publicznych, zanieczyszczeniem środowiska, polaryzacją społeczną oraz zagrożeniem niekontrolowanej suburbanizacji. Generalnie, wskazywane trudności rozwojowe większych miast uzasadniają podejmowaną interwencję publiczna, $\mathrm{w}$ tym prowadzoną $\mathrm{w}$ ramach polityki spójności. Dała ona przede wszystkim tzw. efekt popytowy, związany z realizacją dużych inwestycji infrastrukturalnych i środowiskowych, które znacząco pobudzały lokalną gospodarkę, a koncentrowały się w dużych miastach (43\% udział w wartości projektów „zlokalizowanych”), ale w mniejszym stopniu budowały potencjał rozwojowy miast, w większym przyczyniały się do zbliżenia się do współczesnych standardów cywilizacyjnych. Słabe i pośrednie oddziaływania zidentyfikowano w sferze innowacyjności i sektorze badawczo-rozwojowym. Paradoksalnie intensywny rozwój infrastruktury transportowej z jednej strony poprawiał atrakcyjność i konkurencyjność miast, z drugiej - umożliwiał zagospodarowanie nowych terenów, pogłębił i przyspieszył procesy suburbanizacyjne. Na kluczowe znaczenie poprawy dostępności centrum aglomeracji miejskich ze strefy 
podmiejskiej $\mathrm{w}$ inicjowaniu i przyspieszaniu zjawisk typu urban sprawl zwraca uwagę wielu autorów (por. Zborowski i in. 2008: 473-516; Lisowski, Grochowski 2009; Beim, Tölle 2008: 121-138: Zimnicka, Czernik 2007; Nuissl i in. 2005). Jeśli połączyć to z raczej nikłym wpływem polityki spójności (2004-2006) na rewitalizację miast (brak kompleksowości, głównie modernizacje i estetyka obiektów oraz minimalny wpływ na gospodarkę i sferę społeczną miast) - uprawniona jest konkluzja o minimalnym wpływie polityki spójności na zachodzące w obszarach metropolitalnych procesy dekoncentracji ludności, podmiotów gospodarczych i miejsc pracy.

Spośród rekomendacji warto zwrócić uwagę na postulat uszczegółowienia zakresu i statusu planów zagospodarowania przestrzennego obszarów metropolitalnych (por. wnioski i rekomendacje $\mathrm{z}$ dokumentu Ocena wpływu polityki spójności..., Celińska-Janowicz i in. 2010), ale warto go rozszerzyć na obszary urbanizujące się wszystkich większych miast, zwłaszcza $\mathrm{w}$ odniesieniu do infrastruktury transportowej i budownictwa mieszkaniowego. Plany zagospodarowania przestrzennego takich obszarów powinny mieć charakter kompleksowy i być obligatoryjnym przedmiotem uzgodnień samorządów miasta centralnego i gmin strefy podmiejskiej. Dopiero wówczas dokumenty planistyczne mogłoby w rzeczywisty sposób wpływać na harmonijny rozwój obszarów miejskich, wyznaczając ramy dla procesów suburbanizacji.

$\mathrm{W}$ sumie działania podejmowane $\mathrm{w}$ sferze planistycznej $\mathrm{z}$ reguły nie mają charakteru kompleksowego, a projekty realizowane przez lokalne samorządy terytorialne nie są ani spójne, ani nie wynikają ze współdziałania co najmniej kilku gmin (inwestycje w infrastrukturę transportowa, w tym transport publiczny, przedsięwzięcia środowiskowe, sieć wodociągowa i kanalizacyjna, podłączanie sieci podmiejskich do oczyszczalni ścieków w miastach centralnych, tworzenie przyjaznych przestrzeni publicznych wysokiej jakości, o dużych walorach estetycznych i użytkowych i atrakcyjnych turystycznie).

\section{Polityka miejska w województwie śląskim w zakresie oddziaływania na procesy suburbanizacji}

Analizy z lat 2000-2015 wskazuja że struktura zagospodarowania województwa śląskiego pozostanie policentryczna mimo postępującego procesu metropolizacji i powiązanej z nim polaryzacji i fragmentacji przestrzeni (aglomeracja górnośląska i rybnicka mają charakter policentryczny, aglomeracja częstochowska i bielska monocentryczny); por. Runge 2011: 
55-66. Te ostatnie zjawiska występują zarówno pomiędzy metropolią i peryferiami, jak i wewnątrz układu metropolitalnego, gdzie pogłębiają się podziały pomiędzy często luksusową przestrzenią zamożnych mieszkańców regionu a zdegradowanymi przestrzeniami ubogich grup społecznych.

Można sądzić, że nasilać się będą zjawiska „prywatyzowania” przestrzeni, rozumianych jako zamknięte lub wydzielone obszary (dzielnice, osiedla) miejskie i zwarte przestrzenie „nowych usług miejskich”, lokujących się w zewnętrznych strefach metropolii i miast (centra handlowe, ośrodki rozrywki, parki tematyczne). Można też sądzić, że proces suburbanizacji - czyli przekształcania pierwotnie rolniczych peryferii $\mathrm{w}$ obszary zabudowy jednorodzinnej, z wszystkimi konsekwencjami - ekonomicznymi, społecznymi i przestrzennymi (w tym przede wszystkim rosnącymi publicznymi kosztami rozwoju związanymi z ekstensyfikacją funkcji infrastruktury komunalnej, transportowej, edukacyjnej, zdrowotnej) będzie postępował.

Nie ulega wątpliwości, że w skali kraju i poszczególnych regionów czynnikiem hamującym procesy suburbanizacji są stopniowo nasilające się niekorzystne (negatywne) trendy rozwoju demograficznego. Zjawiska te $\mathrm{w}$ naturalny sposób ograniczają potencjał przepływów miasto - wieś, przede wszystkim w regionach o znaczącym odpływie zewnętrznym ludności, a do takich należy województwo śląskie. Równolegle, niekorzystny kierunek zmian demograficznych w skali regionalnej sprzyja powstawaniu i utrzymaniu się zdegradowanych obszarów w strefach centralnych miast, gdzie kumuluje się ludność o ograniczonych z różnych powodów możliwościach przemieszczeń wewnątrz obszaru miejskiego (Burdack, Hesse 2006: 381-399).

Proces żywiołowej suburbanizacji, przynajmniej częściowo, jest konsekwencją zmian w centralnych częściach obszarów miejskich. Transformacja ustrojowa uruchomiła oddziaływanie renty gruntowej i prawa własności, które „wypychają” wiele funkcji oraz kategorii społecznych na obrzeża miast. Podobne efekty daje reprywatyzacja skutkująca zawłaszczaniem przestrzeni miast, wzrost kosztów funkcjonowania miast i obniżanie jakości życia (Ekspercki projekt... 2008). W województwie śląskim tego typu zjawiska zachodzą na dużą skalę, szczególnie w aglomeracji górnośląskiej, ale również peryferyjne obszary wiejskie (północny wschód i południowy zachód) cechują procesy depopulacyjne. Strefa zewnętrzna aglomeracji górnośląskiej jest jedyną w Polsce, w której procesy suburbanizacji są bardzo słabe, natomiast intensywnie zachodzą wokół Częstochowy i w szerokiej strefie wiejsko-miejskiej wokół Bielska-Białej. 

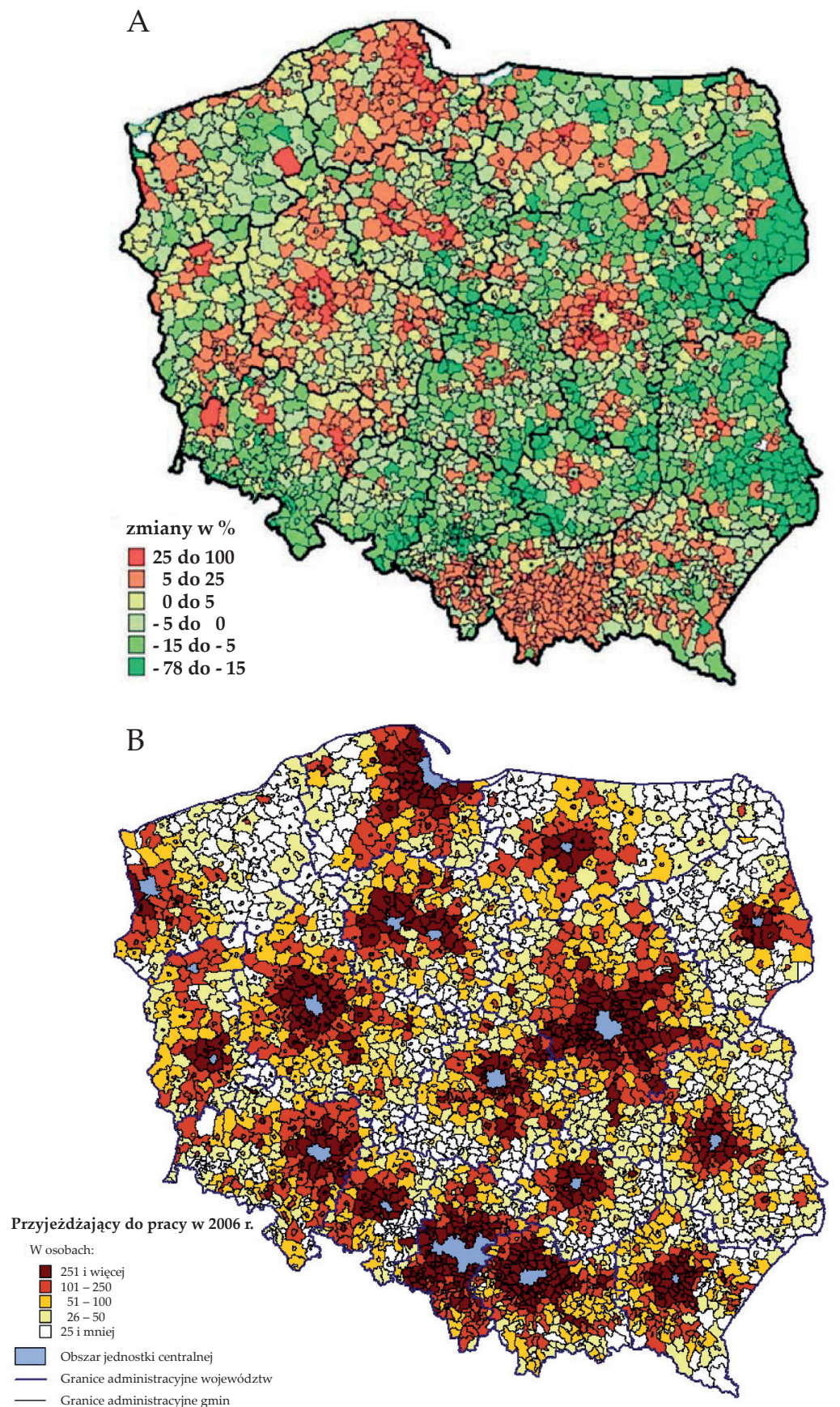

Ryc. 3. Zmiany w gęstości zaludnienia wg gmin w Polsce w latach 1988-2007 (A) i przyjeżdżający do pracy do miast wojewódzkich w 2006 r. Zasięg suburbanizacji (B) Źródło: (Węcławowicz i in. 2010) 
O rzeczywistym wymiarze procesu suburbanizacji w województwie śląskim świadczy zasięg dojazdów do pracy (ryc. 3b), przy czym centralny obszar aglomeracji obejmuje swoim zasięgiem większą część regionu. Kwestia demograficzna - jako uwarunkowanie zasięgu oraz tempa procesów suburbanizacyjnych - bardzo silnie oddziałuje i, jak się wydaje, będzie oddziaływać w przyszłości na postępy tych zmian w regionie. Zachodzą procesy analogiczne do zmian $\mathrm{w}$ regionalnych lub krajowych obszarach peryferyjnych, polegające na wyraźnym trendzie do wyludniania się licznych miejscowości, co stanowi konsekwencję odpływu ludności. W aglomeracji górnośląskiej odpływ kieruje się częściowo do strefy zewnętrznej aglomeracji, do gmin wiejskich i miast zlokalizowanych na obrzeżach strefy metropolitalnej, ale również poza region, głównie do największych miast (Warszawa, Kraków, Poznań), a w strefie zachodniej również za granicę.

Spadek zaludnienia w centralnej części aglomeracji górnośląskiej pociąga za sobą przesunięcie popytu konsumpcyjnego, miejsc pracy i przemysłu oraz usług, szczególnie rynkowych (m.in. regionalne centra handlowe, edukacja podstawowa, ochrona zdrowia); por. Heffner, Twardzik 2011: 55-68. Odpływ kieruje się głównie na obszary wiejskie, nie tylko najbliższe, lecz także bardziej oddalone, co można łączyć z poprawą dostępności komunikacyjnej i transportowej (nowe inwestycje drogowe, tabor autobusowy, dogodne połączenia z centrami miast itd.). Gwałtowny wzrost powierzchni zabudowanych w strefie zewnętrznej aglomeracji górnośląskiej ma wyraźny związek z przesunięciem ludności oraz aktywności gospodarczych do miejscowości wiejskich, położonych nawet w znacznym oddaleniu od centrów miejskich (okolice Częstochowy, Rybnika i Bielska-Białej). Nie obserwuje się natomiast istotnych przyrostów powierzchni zabudowanych w bezpośrednim otoczeniu aglomeracji górnośląskiej, szczególnie w części zachodniej i północno-wschodniej, oraz w szerokim zapleczu wiejskim Rybnika, co można łączyć z osiągnięciem na tyle wysokiego poziomu urbanizacji obszarów wiejskich, że nowe procesy (zajmowanie terenów dotąd nieużytkowanych na dużą skalę) zachodzą znacznie wolniej i mniej intensywnie (por. wnioski Węcławowicz 2010).

Podobnie jak $\mathrm{w}$ innych aglomeracjach miejskich, również $\mathrm{w}$ górnośląskim obszarze metropolitalnym zjawisko suburbanizacji wyjaśniano rozwojem systemów transportu (zbiorowego i indywidualnego), które umożliwiały oddzielenie miejsc pracy i zamieszkania (Dydkowski, Tomanek 2010; Kamiński 2005: 95-101). Łącznie, wymienione czynniki przyczyniają się do wzrostu ludności w strefie zewnętrznej aglomeracji, natomiast negatywnie oddziałują na obszary centralne miast, wypierając z nich typowe funkcje miejskie. Bez odpowiednich działań, mających na celu polepszenie warunków mieszkaniowych w centrach głównych miast, poprawę jakości miejskich przestrzeni publicznych oraz radykalną zmianę ich wizerunku (miasta przemysłowe) trudno taki kierunek zmian odwrócić. 


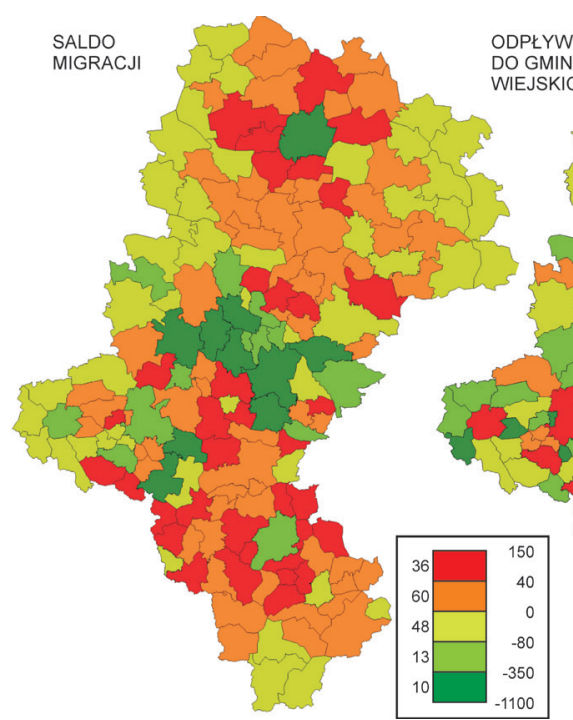

A

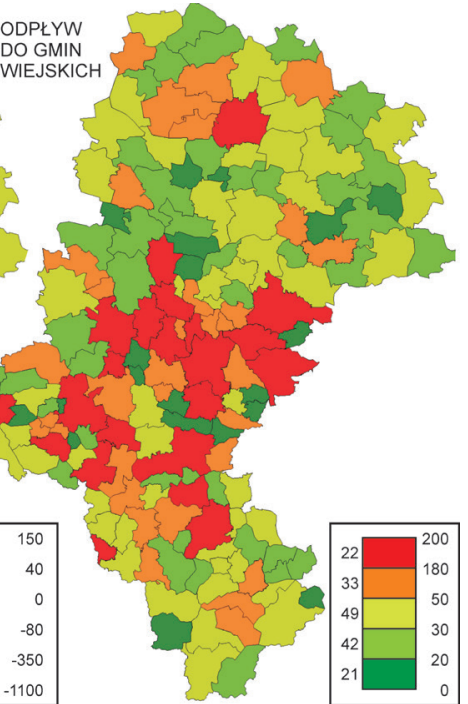

B

Ryc. 4. Saldo migracji wg gmin (A) i odpływ do gmin wiejskich (B) w woj. śląskim w latach 1998-2010 Źródło: oprac. własne (Heffner, Gibas 2014)

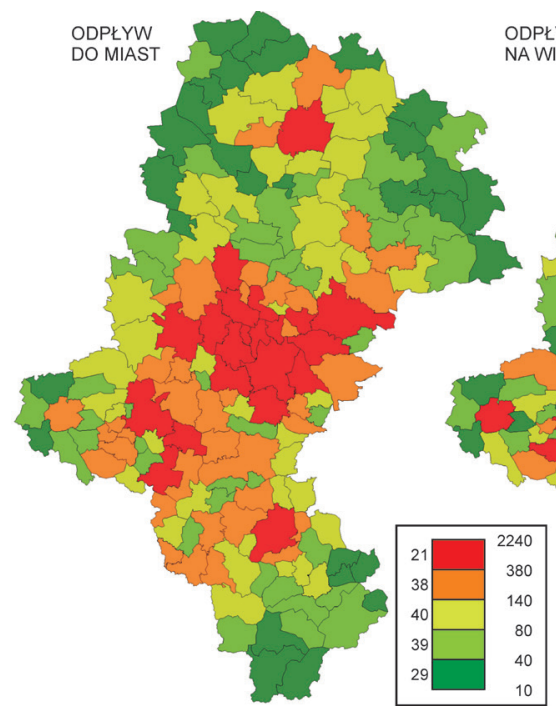

A

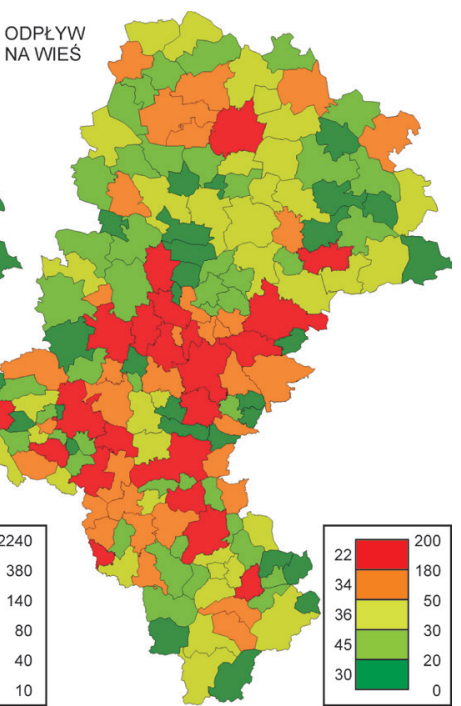

B

Ryc. 5. Odpływ do miast (A) i odpływ na wieś (B) w woj. śląskim w latach 1998-2010 Zródło: jak ryc. 4 


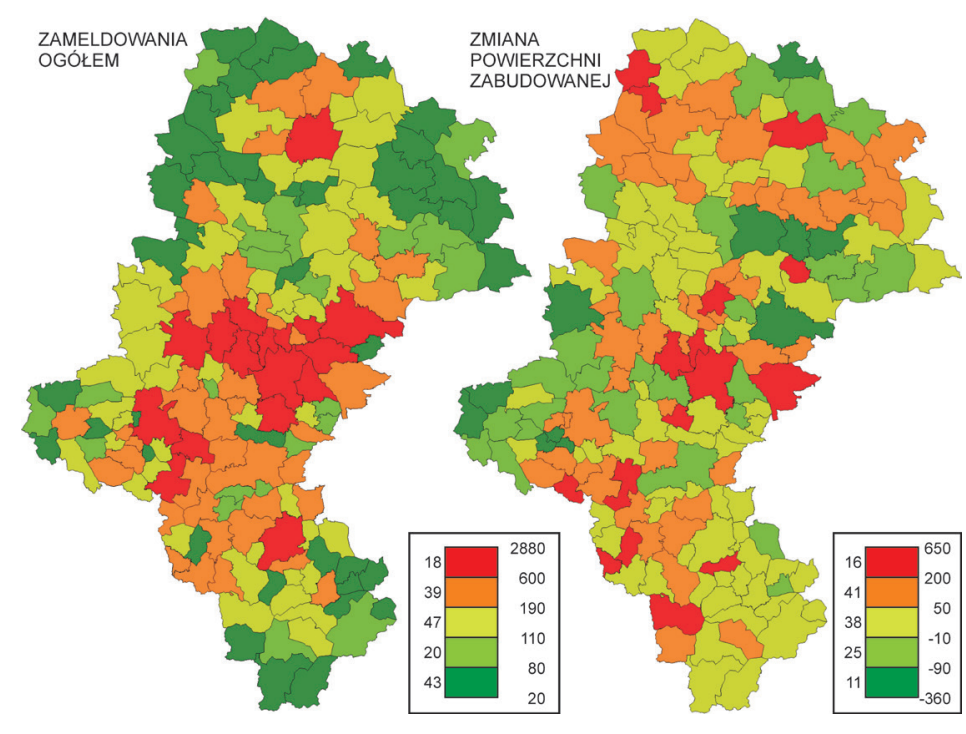

A

B

Ryc. 6. Zameldowania ogółem wg gmin woj. śląskiego 1998-2010 (A), zmiana powierzchni zabudowanej (1990-2006) (B) Źródło: jak ryc. 4

W latach 2002-2009 powierzchnia gruntów zabudowanych i zurbanizowanych w województwie śląskim wzrosła o ok. 28000 ha (zmiana udziału tej kategorii użytków z ok. 9\% do 11,2\% powierzchni), głównie kosztem użytków rolnych. Wzrost dotyczył przede wszystkim gmin wiejskich i miejsko-wiejskich z szerokiego otoczenia Częstochowy i rejonu pomiędzy Rybnikiem i Bielskiem-Białą. Tendencja ta może się utrzymać, chociaż nie jest tak silna jak w największych aglomeracjach monocentrycznych kraju (Warszawa, Kraków) ze względu na niesłabnący odpływ ludności miejskiej oraz działalności gospodarczej poza główne ośrodki miejskie regionu (Analiza zmian... 2009; Gutry-Korycka i in. 2005: 53-82).

W sytuacji rosnącego znaczenia jakości życia jako czynnika konkurencyjności miast i regionów oczekiwania społeczne wobec walorów przestrzeni publicznych szybko rosną. Rewitalizacja (niestety ciągle rzadko traktowana kompleksowo) wielu obszarów miejskich, rozumiana jako działanie obniżające i hamujące presję związaną z nowymi potrzebami mieszkańców, skutkuje ekspansją na niezagospodarowane dotąd tereny wiejskie. Procesy rewitalizacyjne w miastach powinny być katalizatorem przekształceń $\mathrm{w}$ ich strukturze oraz $\mathrm{w}$ strefach powiązanych funkcjonalnie, a także $\mathrm{w}$ całych subregionach i regionach (m.in. nowe funkcje kulturalne, społeczne, rekreacyjne i sportowe dla rewitalizowanych i re- 
strukturyzowanych obiektów przemysłowych i logistycznych). Nowe formy rekreacji wymuszają zmianę tradycyjnych, często zdegradowanych, przestrzeni w specyficzne, nowe formy jej użytkowania (Kupiec 2011). Przewartościowania wymagają dotychczasowe sposoby prowadzenia polityki rewitalizacji i restrukturyzacji centrów miejskich w skali regionu śląskiego (rozproszenie projektów, głównie modernizacyjna, często odtwórcza formuła - o tych i wielu innych wadach działań rewitalizacyjnych podejmowanych przed $2010 \mathrm{r}$. raport Ocena wpływu polityki spójności..., Celińska-Janowicz i in. 2010), jednak selektywna i skoncentrowana forma jej prowadzenia może zdecydowanie osłabić presję suburbanizacyjną. W skali regionu śląskiego ma ona charakter zdecydowanie żywiołowy, „wymyka się” obowiązującym regulacjom z zakresu gospodarki przestrzennej (o żywiołowości suburbanizacji i jej negatywnym skutkach w woj. śląskim wspominają m.in. Z. J. Kamiński, J. Runge, T. Kupiec, a także zespół F. Kuźnika (2009)).

Głównym problemem jest brak kompleksowej polityki traktowania regionów miejskich (miast i powiązanych z nimi obszarów wiejskich) jako struktur przestrzennych, wymagających zharmonizowanego rozwoju (brakuje politycznej gotowości do wdrożenia takiego systemu, jakkolwiek presja społeczna oraz płynąca ze strony środowisk naukowych świadomość potrzeb w tym zakresie jest silna).

\section{Zamiast wniosków - władze publiczne i oddziaływanie na procesy suburbanizacji}

Kwestia ograniczenia negatywnych skutków rozproszonej suburbanizacji jest już przedmiotem dyskusji od kilkudziesięciu lat. Jak się wydaje, powstrzymanie procesów suburbanizacji jest zadaniem bardzo trudnym, ale zapanowanie nad nimi, choć niezwykle trudne, wydaje się jednak wykonalne. Nie będzie to jednak możliwe bez głębokich zmian w praktyce i podejściu do zarządzania rozwojem, gospodarowania przestrzenią i planowania przestrzennego. W Polsce zjawisko urban sprawl wywołują: polityka władz lokalnych, strategia deweloperów i charakterystyczne preferencje mieszkaniowe stosunkowo wąskiej klasy średniej; inne czynniki mają drugoplanowe znaczenie. O intensywności i zasięgu urban sprawl decydują dwa czynniki (wg badań amerykańskich):

- wzrost liczby osób gotowych zamieszkać poza miastem centralnym, w obszarze o mniejszej gęstości domów, ale w strefie, gdzie postępuje intensywna suburbanizacja;

- preferencje mieszkańców miast (tzw. per capita sprawl), którzy nie tylko chcą mieszkać poza miastem, lecz także dysponować dużymi działkami 
budowlanymi, co prowadzi do zwiększenia średniej wielkości terenów miejskich na jednego mieszkańca. Innymi słowy, każdy mieszkaniec miasta wykorzystuje coraz większy obszar miejski.

Niekontrolowana ekspansja zabudowy miejskiej na obszary wiejskie przyczynia się do nawarstwiania się wielu problemów środowiskowo-przestrzennych i społeczno-kulturowych (m.in. ruderalizacja oraz niszczenie obszarów leśnych i roślinności, wzrost zanieczyszczenia powietrza i wody, zubożenie gleby, rozerwanie wiejskich schematów urbanistycznych, więzów sąsiedzkich, powiązań łączących tradycyjnie mieszkańców małe miasta i wsie). Dodatkowym, negatywnym skutkiem suburbanizacji w Polsce jest wzrost podatków i innych opłat komunalnych na obszarach nowo zurbanizowanych (Suburbanizacja... 2010; Czerny 2005; Litwińska 2008; więcej: www.sprawlcity.org).

Istotnym skutkiem rozlewania się miast jest także degradacja ich centralnych dzielnic i niewykorzystywanie możliwości racjonalnego zagospodarowania ich przestrzeni. Dlatego działania zmierzające do redukcji negatywnych skutków procesu nie mogą się ograniczać tylko do strefy suburbanizacji, ale muszą uwzględniać sytuację $\mathrm{w}$ miastach centralnych - im lepiej funkcjonują w sensie ekonomiczno-społecznym, zarówno w układach ponadregionalnych, jak i lokalnych, tym większa presja 102 urbanizacyjna w strefie zewnętrznej. Wynika ona zarówno z chęci podtrzymywania więzi gospodarczych i społeczno-kulturowych z rozwijającym się ośrodkiem, jak i z wzrastających aspiracji dotyczących poziomu życia mieszkańców (Dijkstra 2013: 251-268). Określenie zasad i zakresu urbanizacji obszarów podmiejskich, umożliwiające utrzymanie ich atrakcyjności lokalizacyjnej, jest podstawowym wyzwaniem dla władz lokalnych, wymaga bowiem kooperacji i wspólnego planowania. Postulat wprowadzenia wspólnego zarządzania na obszarach metropolitalnych ma uzasadnienie tylko wówczas, gdy jest efektem porozumienia równoprawnych i dobrowolnych uczestników. Znaczenie mają tu zarówno problemy strefy sąsiadującej z miastem centralnym (żywiołowa suburbanizacja), jak i trudności rozwojowe ośrodka centralnego, wreszcie kwestie międzyregionalne.

Zbyt daleko idące regulacje, formalizm, interwencjonizm administracyjny - mogą spotkać się nawet ze zorganizowanym oporem społecznym. W sumie, przesunięcie populacji do strefy zewnętrznej aglomeracji miejskich wynika z szeroko rozumianej chęci mieszkańców obszarów metropolitalnych, a szerzej: większych miast, do podnoszenia jakości życia. Uważa się, że największym wyzwaniem jest zmiana postaw społecznych, przekonanie do dystrybutywnego charakteru korzyści, płynących z realizacji ładu przestrzennego oraz uznanie tych zasad za przesłanki $w$ indywidualnych działaniach podmiotów (Celińska-Janowicz i in. 2010). Ogra- 
niczenie negatywnych skutków suburbanizacji na poziomie lokalnym wymaga oszczędnego gospodarowania ziemia, intensyfikacji wykorzystania terenów już zainwestowanych, rewitalizacji zdegradowanych, zwiększenia wielofunkcyjności nowych struktur osadniczych, łączenia funkcji komplementarnych, eliminacji konfliktów funkcji i negatywnych oddziaływań nowych inwestycji oraz stymulowania procesów integracji społecznej starych i nowych mieszkańców suburbiów i stref rezydencjonalnych (Beim, Tölle 2008: 121-138; Litwińska 2008: 42-43; Rembarz 2005; Zborowski i in.2008; Bagiński [red.] 2000).

Nadawanie ram i stymulowanie procesów wzrostu w jednostkach terytorialnych stref podmiejskich z jednej strony wymusza posługiwanie się standardowymi narzędziami prawno-administracyjnymi i procedurami planistycznymi, z drugiej - może być polem współpracy władz lokalnych i regionalnych, partycypacji lokalnych społeczności, marketingu miejskiego (przyciagganie do pewnych lokalizacji inwestorów i deweloperów), współdziałania samorządów w projektach infrastrukturalnych, wspieranych środkami zewnętrznymi. Do grupy instrumentów o charakterze indykatywno-kontrolnym należą przede wszystkim uregulowania z zakresu planowania przestrzennego (wymagają one daleko idących przewartościowań i uściśleń w istniejących przepisach), które umożliwiają oddziaływanie na rodzaj, funkcje, a także intensywność zagospodarowania (gęstość zabudowy, zapewnienie sukcesji funkcji, ograniczenie zagospodarowywania nowych terenów, uzależnienie podjęcia kolejnych inwestycji od wyposażenia w infrastrukturę itd.).

Niezwykle skutecznym sposobem oddziaływania na procesy przestrzenne są instrumenty ekonomiczne (odpowiednie podatki preferencyjne, zaporowe, subsydia, dotacje itp.). Ich rolą jest zachęcanie do inwestowania w określonych miejscach i w pożądanej formie, mogą wzmacniać procesy rewitalizacyjne i gentryfikacyjne $\mathrm{w}$ centrach miast, zmniejszając presję na obszary zewnętrzne. W tej grupie narzędzi są też inwestycje publiczne - realizowane $\mathrm{w}$ newralgicznych rejonach miast $\mathrm{i}$ ich otoczeniu, spowalniające lub eliminujące żywiołową suburbanizację. Dużą rolę odgrywają również instrumenty miękkie (lobbowanie za partycy pacją lokalnych społeczności, edukacja mobilizująca mieszkańców i radnych do działania zgodnie z zasadami zrównoważonego rozwoju, większe uspołecznienie procesu planowania przestrzennego, przepływ informacji o zmianach w zagospodarowaniu - określenie optymalnej pojemności obszaru, dalsze lokowanie funkcji, skala zmian w użytkowaniu terenów).

Biorąc pod uwagę osiągnięty stan zagospodarowania przestrzennego kraju oraz uwarunkowania i trendy występujące w procesie suburbanizacji, można sformułować kilka ogólniejszych przesłanek racjonalizujących dalsze zmiany: 
- strefy podmiejskie metropolii i miast o znaczącym poziomie zurbanizowania powinny być intensywniej wykorzystane i wskazywane jako potencjalne obszary dalszego zagospodarowania pod zabudowę mieszkaniową i inna;

- dychotomiczna suburbanizacja poprzez uporządkowanie i segregację terenów pod zabudowę różnicuje obszary w strefach podmiejskich na intensywnie zagospodarowane (zwarta zabudowa) i wykorzystywane dla utrzymania funkcji środowiskowych i rolniczych;

- intensyfikacja zabudowy wyłącznie przez uzupełnianie i rewitalizację lub rekultywację terenów już zajętych (przeciwdziałanie ekstensywnemu wykorzystaniu terenów i wkraczaniu zabudowy na tereny otwarte);

- dążenie do pełnego wykorzystywania potencjału istniejącej infrastruktury technicznej (np. powrót do koncepcji progowego rozwoju miast) i jej ewentualna rozbudowa tylko w ekonomicznie uzasadnionych przypadkach;

- preferencje dla intensywnych form transportu w wiejskich strefach zurbanizowanych (m.in. transport publiczny).

Punktem wyjścia powinna być analiza pojemności środowiskowej, skali dodatkowej antropopresji oraz wpływu potencjalnego zagospodarowania terenu na funkcjonowanie całego obszaru metropolitalnego (Węcła104 wowicz i in. 2010). Wybór terenów, które mogą być polem dalszej intensyfikacji użytkowania obszarów wiejskich w zasięgu oddziaływania miasta musi uwzględniać przede wszystkim kwestie ekonomiczne - bieżące i perspektywiczne w kierunku obniżania ogólnych kosztów użytkowania. Ponadto konieczna jest preferencja dla terenów z zachowanymi walorami przyrodniczymi czy rolniczymi, wyłączonymi spod presji urbanizacyjnej w skali subregionalnej i ponadlokalnej.

Ze względu na brak restrykcyjnych instrumentów prawnych, które mogą ograniczyć żywiołowy wzrost obszarów urbanizujących się, rekomenduje się rozwiązania wskazujące potencjalne strefy suburbanizacji wg kilku kryteriów:

- minimalizacja kosztów użytkowania terenu;

- preferencje w zagospodarowaniu pod zabudowę terenów rewitalizowanych i restrukturyzowanych wewnątrz obszarów administracyjnych miast;

- podtrzymywanie jakości środowiska przyrodniczego;

- zachowanie obszarów ważnych dla systemów przyrodniczych miasta i jego otoczenia;

- potencjalny wpływ na strukturę funkcjonalno-przestrzenną całego obszaru;

- podejście typu progowego do wyposażenia terenów w infrastrukturę techniczną i społeczną. 
Można w ten sposób istotnie zmniejszyć konsumpcję gruntów niezurbanizowanych $\mathrm{w}$ obszarach metropolitalnych i w strefach urbanizujących się innych miast. Podejście to może w większym stopniu umożliwić równoważenie rozwoju obszarów poddawanych dotąd antropopresji oraz przeciwdziałać chaosowi przestrzennemu i funkcjonalnemu w wiejskim otoczeniu większych ośrodków miejskich (Węcławowicz i in. 2010). Niekontrolowana ekspansja mieszkańców miast i sprzyjająca jej rozrzutna polityka zagospodarowania przestrzennego gmin wiejskich i miejsko-wiejskich zmniejsza efektywność funkcjonowania transportu zbiorowego, powiększa jego koszty.

Suburbanizacja, łącząca się z migracyjnym przepływem bardziej zamożnych mieszkańców z dzielnic centralnych na przedmieścia, codziennymi dojazdami do pracy w centrum, ale z drugiej strony "oferująca" zdecydowanie lepsze warunki życia, jest procesem trwałym dopóty, dopóki nie ulegną wyczerpaniu zasoby (ludzkie), zasilające proces przepływu między tymi strefami. Przepływ w kierunku obszarów wiejskich otaczających miasta jest trwały, dokąd mieszkańcy umacniają swoją pozycję kapitałową (rozwój gospodarczy) i reprezentują zespół cech społeczno-demograficznych, sprzyjających takiej zmianie miejsca zamieszkania. Procesy suburbanizacji, powiększają ekstensywny obszar wymagający obsługi komunikacyjnej (Dydkowski, Tomanek 2010), podwyższając koszty funkcjonowania całych układów miejskich ze wszystkimi negatywnymi, społecznymi, gospodarczymi i przestrzenno-środowiskowymi skutkami.

\section{Literatura}

Aguilera A., Mignot D. (2004), Urban sprawl, polycentrism and commuting. A comparison of seven French urban areas, "Urban Public Economics Review" No. 1, s. 93-113.

Analiza zmian w zakresie struktury własności i sposobów użytkowania gruntów w województwie ślaskim na przestrzeni lat 2002-2009 (2009), UM Województwa Śląskiego, Katowice.

Bagiński E. [red.] (2000), Wrocław i strefa przymiejska jako układ osadniczy w interdyscyplinarnych badaniach planistów przestrzennych, Wydz. Architektury Politechniki Wrocławskiej, Oficyna Wydawnicza PW, Wrocław.

Bagiński E. (2001), Suburbanizacja - nieunikniona przyszłość osadnictwa?, [w:] J. Słodczyk (red.), Procesy suburbanizacji w wybranych miastach Polski, Uniwersytet Opolski, Opole, s. $11-16$.

Beim M. (2009), Modelowanie procesu suburbanizacji w aglomeracji poznańskiej, Bogucki Wydawnictwo Naukowe, Poznań.

Beim M., Tölle A. (2008), Motywacje migracji rezydencjalnych w obszarze aglomeracji poznańskiej, [w:] T. Kaczmarek, A. Mizgajski (red.), Jakość przestrzeni i jakość życia, Bogucki Wydawnictwo Naukowe, Poznań, s. 121-138.

Bontje M. (2004), From Suburbia to Post-Suburbia in the Netherlands: Potentials and Threats for Sustainable Regional Development, "Journal of Housing and the Built Environment", Vol. 19, No. 1, s. 25-47. 
Brake K., Dangschat J., Herfert G. (2001), Suburbanisierung in Deutschland - Aktuelle Tendenzen, Opladen.

Breheny M. (2003), Centrists, Decentrists and Compromisers: Views on the Future of Urban Form, [w:] E. Burton, M. Jenks, K. Williams (eds.), The Compact City: A Sustainable Urban Form?, Routledge, London, s. 10-29.

Budziński M., Kmieć B., Kmieć T., Raczek M., Wrana K., Wrana W. (2014), Diagnoza potencjału rozwojowego obszaru funkcjonalnego zlokalizowanego wzdłuż autostrady A-1 na terenie subregionu zachodniego województwa ślaskiego, Fundacja Kreatywny Śląsk, Rybnik.

Burdack J., Hesse M. (2006), Reife Stagnation oder Wende? Perspektiven zu Suburbanisierung, Post-Suburbanisierung und Zwischenstadt: Ein Überblick zum Stand der Forschung, "Berichte zur deutschen Landeskunde“ 80 (4), s. 381-399.

Celińska-Janowicz D., Kozak M., Miszczuk A., Płoszaj A., Smętkowski M., Tucholska A., Wojnar K. [red.] (2010), Ocena wpływu polityki spójności na rozwój miast polskich (w ramach ewaluacji ex post NPR 2004-2006), Centrum Europejskich Studiów Regionalnych i Lokalnych EUROREG Uniwersytetu Warszawskiego, Warszawa.

Champion T. (2001), Urbanization, suburbanization, counterurbanization and reurbanization, [w:] R. Paddison (ed.), Handbook of urban studies, Sage Publications, London, s. 143161.

Czarnecki A. (2005), Obszary wiejskie, urbanizacja wsi, rozwój wielofunkcyjny, rolnictwo wielofunkcyjne - przegląd pojęć, [w:] A. Rosner (red.), Uwarunkowania i kierunki przemian społeczno-gospodarczych na obszarach wiejskich, IRWiR PAN, Warszawa, s. 233-254.

Czarnecki A. (2009), Rola urbanizacji w wielofunkcyjnym rozwoju obszarów wiejskich, IRWiR PAN, Warszawa.

Czarnecki B. (2011), Przejawy i konsekwencje depopulacji polskich miast. Zarys problemu, „Architecturae et Artibus", nr 4.

Czernik L. (2007), Wieś w procesie suburbanizacji na przykładzie wybranych wsi południowej Anglii, „Przestrzeń i Forma”, nr 7-8, s. 317-332.

Czernik L. (2008), Struktura osadnictwa wiejskiego w strefie suburbanizacji Hamburga, „Przestrzeń i Forma", nr 10, s. 215-232.

Czerny M. (2005), Globalizacja a rozwój, Warszawa.

Dear M. J. (2000), The Postmodern Urban Condition, Blackwell, Oxford.

Delden B. van (2011), Twenty-five years of compact city policy, [w:] L. Boelens, H. Ovink, H. L. Palsdottir, E. Wierenga (eds.), Compact city extended: outline for future policy research and design, 010 Publishers, Rotterdam, s. 154-172.

Dijkstra L. (2013), What future for regional policy? Why investing more in the capital can lead to less growth, "Cambridge Journal of Regions, Economy and Society", Vol. 6, No. 2, s. 251-268.

Dydkowski G., Tomanek R. (2010), Strategia rozwoju zbiorowego transportu miejskiego w Gliwicach. Identyfikacja i ocena opcji strategicznych, Centrum Badań i Ekspertyz Uniwersytetu Ekonomicznego w Katowicach, Katowice.

Dziekoński O. R. (2008), Polityka miejska - rozwój obszarów zurbanizowanych, Ministerstwo Infrastruktury, Warszawa [pdf - prezentacja].

Ekspercki projekt Koncepcji Przestrzennego Zagospodarowania Kraju do roku 2033 (2008), Instytut Geografii i Przestrzennego Zagospodarowania PAN, MRR, Warszawa.

Gottdiener M., Hutchison R. (1999), The New Urban Sociology, Mc Graw-Hill Companies, New York.

Gottdiener M., Kephart G. (1991), The multinucleated metropolitan region: a comparative analysis, [w:] R. Kling, S. Olin, M. Poster (eds.), Postuburban California. The Transformation of Orange County Since World War II, University of California Press, Berkeley, s. 31-54. 
Gutry-Korycka M., Zegar T., Ostrowski W. (2005), The conversion of rural land-use to urban sprawl, [w:] M. Gutry-Korycka (ed.), Urban sprawl - Warsaw Agglomeration Case Study, Wyd. Uniwersytetu Warszawskiego, Warszawa 2005, s. 53-82.

Heffner K. (2000), Typologia gmin wiejskich w Polsce pod katem widzenia układów osadniczych, [w:] A. Rosner (red.), Lokalne bariery rozwoju obszarów wiejskich, Fundacja Programów Pomocy dla Rolnictwa, Warszawa, s. 65-85.

Heffner K. (2008), Problematyka zwiazana z procesami semiurbanizacji w woj. opolskim, [w:] T. Markowski, Z. Strzelecki, Obszary urbanizacji i semiurbanizacji wsi polskiej a możliwości ich rozwoju w ramach PROW 2007-2013, „Studia KPZK PAN”, t. 119, s. 57-71.

Heffner K. (2011a), Problemy zagospodarowania przestrzeni wiejskiej, [w:] I. Nurzyńska, M. Drygas (red.), Rozwój obszarów wiejskich w Polsce. Diagnozy, strategie, koncepcje polityki, Instytut Rozwoju Wsi i Rolnictwa PAN, Warszawa 2011, s. 175-194.

Heffner K. (2011b), Wielofunkcyjność obszarów wiejskich w Polsce-rzeczywistość czy mit? Ewolucja zagospodarowania przestrzeni wiejskiej, [w:] W. Kamińska, K. Heffner (red.), Obszary wiejskie. Wielofunkcyjność, migracje, nowe wizje rozwoju, „Studia KPZK PAN”, t. 133, s. 8-26.

Heffner K., Czarnecki A. (2011c), Wpływ zjawiska drugich domów na rozwój obszarów wiejskich, [w:] K. Heffner, A. Czarnecki (red.), Drugie domy w rozwoju obszarów wiejskich, Instytut Rozwoju Wsi i Rolnictwa PAN, Warszawa, s. 131-162.

Heffner K., Gibas P. (2014), Zróżnicowanie procesów społecznych, gospodarczych i inwestycyjnych w układach sasiadujacych gmin miejskich $i$ wiejskich ( $t z w$. gmin obwarzankowych), ekspertyza, Ośrodek Kultury Wzgórze Zamkowe, Lubin.

Heffner K., Marszał T. (2011), Wprowadzenie, [w:] K. Heffner, T. Marszał (red.), Rewitalizacja. Gentryfikacja i problemy rozwoju matych miast, „Studia KPZK PAN”, t. 136, s. 5-7.

Heffner K., Twardzik M. (2011), Centra handlowe w projektach rewitalizacji matych miast w województwie ślaskim, [w:] K. Heffner, T. Marszał (red.), Rewitalizacja. Gentryfikacja i problemy rozwoju matych miast, „Studia KPZK PAN”, t. 136, s. 55-68.

Houtum H. van, Lagendijk A. (2001), Contextualizing Regional Identity and Imagination in the Construction of Polycentric Urban Regions: The Cases of the Ruhr Area and the Basque Country, "Urban Studies", Vol. 38, No. 4, s. 747-767.

Jackson K. T. (1985), Crabgrass Frontier: The Suburbanization of the United States, Oxford University Press, New York.

Kajdanek K. (2011), Pomiędzy miastem a wsia. Suburbanizacja na przykładzie osiedli podmiejskich Wrocławia, Nomos, Kraków 2011.

Kamiński Z. J. (2005), Sterowanie procesami suburbanizacji w obszarze wzajemnych oddziatywań Katowic i Krakowa. Spojrzenie z perspektywy Katowic, "Czasopismo Techniczne”, R. 102, z. 15-A, s. 95-101.

Kaplan D., Wheeler J. O., Hodler T. W., Holloway S. R. (2004), Urban Geography, John Wiley and Sons, Hoboken, NJ.

Klasik A., Kuźnik F., Biniecki J., Szczupak B., Baron M., Ochojski A. (2009), Stan i potencjały endogenicznego rozwoju metropolitalnych ustug publicznych GOM, Akademia Ekonomiczna im. Karola Adamieckiego w Katowicach, Katowice. Projekt Foresight technologiczny rozwoju sektora usług publicznych w Górnoślaskim Obszarze Metropolitalnym realizowany w ramach: poddziałania 1.1.1 Projekty badawcze z wykorzystaniem metody foresight Programu Operacyjnego Innowacyjna Gospodarka. Ekspertyza nr 2.

Kozielska B. (2008), Wspótczesne koncepcje rozwoju metropolii w kontekście paradygmatu miast globalnych, Wydział Nauk Społecznych, Uniwersytet Śląski, Katowice, oai:www.sbc. org.pl: 11974.

Krajowa Polityka Miejska, (2014), projekt, wersja I, Ministerstwo Infrastruktury i Rozwoju, Warszawa, https://www.mir.gov.pl/strony/zadania/polityka-rozwoju-kraju/polityka-miejska/. 
Krajowa Strategia Rozwoju Regionalnego 2010-2020: Regiony, Miasta, Obszary wiejskie (2010), Ministerstwo Rozwoju Regionalnego, Warszawa.

Krzysztofik R. (2007), Aglomeracja rybnicka. Zarys typologii osadniczej, Urząd Miasta Rybnika, Rybnik.

Kupiec T. (2011), Społeczne, gospodarcze i polityczne uwarunkowania i konsekwencje zróżnicowanego tempa wzrostu gospodarczego subregionów województwa ślaskiego, [w:] Wyzwania zrównoważonego użytkowania terenu na przykładzie województwa śląskiego - scenariusze 2050, Katowice.

Lisowski A. (2005a), Janusowe oblicze suburbanizacji, [w:] I. Jażdżewska (red.), Współczesne procesy urbanizacji i ich skutki, XVIII Konwersatorium Wiedzy o Mieście, Katedra Geografii Miast i Turyzmu, Uniwersytet Łódzki, Łódź, s. 91-100.

Lisowski A. (2005b), Urban sprawl process, [w:] M. Gutry-Korycka (ed.), Urban Sprawl - Warsaw Agglomeration Case Study, Wyd. Uniwersytetu Warszawskiego, Warszawa, s. 8399.

Lisowski A., Grochowski M. (2009), Procesy suburbanizacji. Uwarunkowania, formy, konsekwencje, „Biuletyn KPZK PAN, nr 240, t. 1, s. 216-280.

Liszewski S. (1987), Strefa podmiejska jako przedmiot badań geograficznych, „Przegląd Geograficzny", t. 59, z. 1-2, s. 65-80.

Litwińska E. (2008), Zjawisko „urban sprawl” - jeden z wymiarów współczesnych procesów urbanizacji, [w:] J. Słodczyk, M. Śmigielska (red.), Współczesne kierunki i wymiary procesów urbanizacji, Wyd. Uniwersytetu Opolskiego, Opole, s. 42-43.

Mielczarek M. (2011), Zmiany funkcjonalne w gminie wiejskiej Kruszyna pod wpływem oddziatywania Częstochowy, Uniwersytet Ekonomiczny w Katowicach, Katowice, praca magisterska.

Nuissl H., Rink D., Steuer P. (2005), The Consequences of Urban Sprawl in a Context of Decline: The Case of Leipzig, "UFZ-Discussion Papers" 7, UFZ Centre for Environmental Research Leipzig-Halle GmbH, Department of Urban and Environmental Sociology, Leipzig.

Ouředniček M., Posova D. (2006), Suburbánní bydlení v Pražském městském regionu: etapy vyvoje a prostorové rozmístnění, [w:] M. Ouředniček (red.), Sociální geografie pražského městského regionu, Univerzita Karlova, Centrum pro vyzkum měst a regionů Přírodovědecké fakulty Univerzity Karlovy v Praze, Univerzita Karlova v Praze, Praha, s. $96-113$.

Palang H., Peil T. (2010), Mapping future through the study of the past and present: Estonian suburbia, "Futures", Vol. 42(7), s. 700-710.

Pankau F. (2011), Uwarunkowania zewnętrzne polityki miejskiej-europejskie i krajowe, Departament Rozwoju Regionalnego i Przestrzennego, Urząd Marszałkowski Województwa Pomorskiego, Gdańsk [pdf].

Parteka T. (2005), Warunki transformacji zdegradowanych struktur miejskich w procesie suburbanizacji, [w:] P. Lorens (red.), Problem suburbanizacji, Urbanista, Warszawa.

Parysek J. (2008), Suburbanizacja i reurbanizacja: dwa bieguny polskiej urbanizacji, [w:] J. Parysek, T. Stryjakiewicz (red.), Region społeczno-ekonomiczny i rozwój regionalny, Bogucki Wydawnictwo Naukowe, Poznań, s. 281-286.

Polit A. (2010), Idea miasta zwartego a rzeczywistość, „Czasopismo Techniczne”, z. 14, 6-A, s. 85-91.

Rakowska J., Wojewódzka-Wiewiórska A. (2010), Zróżnicowanie przestrzenne obszarów wiejskich w Polsce - stan i perspektywy rozwoju w kontekście powiazań funkcjonalnych, ekspertyza wykonana na zamówienie Ministerstwa Rozwoju Regionalnego, SGGW, Warszawa. 
Reckien D., Karecha J. (2007), Sprawl in European Cities: The Comparative Background, [w:] C. Couch, L. Leontidou, G. Petschel-Held (eds.), Urban Sprawl in Europe. Landscapes, Land-Use Change \& Policy, Blackwell, Oxford, s. 39-67.

Rembarz G. (2005), Wzajemna zależność procesów kurczenia i suburbanizacji na przykładzie miast niemieckich, [w:] P. Lorens (red.), Problem suburbanizacji, Urbanista, Warszawa.

Runge J. (2011), Społeczno-gospodarcze oraz przestrzenne przejawy suburbanizacji w województwie ślaskim, [w:] J. Słodczyk (red.), Procesy suburbanizacji w wybranych miastach Polski, Uniwersytet Opolski, Opole, s. 55-66.

Rusk D. (1995), Cities without Suburbs, Woodrow Wilson Center Press, Washington.

Saaty T. L. (2013), Compact City: The next urban evolution in response to climate change, RWS Publications, Pittsburgh.

Scott A. J., Agnew J., Soja E. W., Storper M (2001)., Global City-Regions, [w:] A. J. Scott (ed.), Global City-Regions: Trends, Theory, Policy, Oxford University Press, New York, s. 11-30

Sieverts T. (2003), Cities without cities: an interpretation of the Zwischenstadt, Spon Press, London.

Sługocki W. (2011), Koncepcja przyszłej krajowej polityki miejskiej w Polsce, Konferencja „Miasta w polityce rozwoju", Warszawa 28.03.2011, Ministerstwo Rozwoju Regionalnego, Warszawa.

Sobala-Gwosdz A. [red.] (2010), Badanie trendów rozwojowych w województwie ślaskim poprzez wyznaczenie ośrodków wzrostu i obszarów stagnacji, STRADA Consulting Piotr Kurowski, Bielsko-Biała.

Staszewska S. (2012), Przeksztatcenia urbanistyczne osiedli wiejskich strefy podmiejskiej dużego miasta, „Barometr Regionalny”, nr 4, s. 53-68.

Straszewicz L. (1959), The Eódź industrial district as a subject of investigations in economic geography, „Przegląd Geograficzny”, t. 31 (Supp.), s. 69-91.

Strzelecki Z., Kucińska M. (2006), Żywiołowe rozprzestrzenianie się metropolii warszawskiej, [w:] S. Kozłowski (red.), Żywiołowe rozprzestrzenianie się miast-narastajacy problem aglomeracji miejskich w Polsce, KUL-PAN, Białystok-Lublin-Warszawa, s. 125-150.

Suburbanizacja i ekspansja miasta na tereny wiejskie - „urban sprawl” (2010), http://stosunki-miedzynarodowe.pl/globalizacja/961-suburbanizacja-i-ekspansja-miasta-na-tereny-wiejskie-urban-sprawl.

Sytuacja demograficzna Polski, Raport 2003 (2004), Rządowa Rada Ludnościowa, GUS, Warszawa.

Tacoli C. (2003), The links between urban and rural development, "Environment and Urbanization", Vol. 15, No. 1, s. 3-12.

Walker A. R. (1981), A Theory of Suburbanization, [w:] M. Dear, A. J. Scott (red.), Urbanization and Urban Planning in Capitalist Society, Methuen, New York, s. 383-429.

Węcławowicz G. (2007), Geografia społeczna miast, Wydawnictwo Naukowe PWN, Warszawa.

Węcławowicz G., Łotocka M., Baucz A. (2010), Rozwój miast w Polsce, Raport wprowadzający Ministerstwa Rozwoju Regionalnego na potrzeby przygotowania Przeglądu OECD krajowej polityki miejskiej w Polsce, Ministerstwo Rozwoju Regionalnego, Warszawa..

Wilkin, J. (2007), Obszary wiejskie w warunkach dynamizacji zmian strukturalnych, [w:] Ekspertyzy do Strategii Rozwoju Społeczno-Gospodarczego Polski Wschodniej do roku 2020, t. 1, Ministerstwo Rozwoju Regionalnego, Warszawa.

Whioski z piątego sprawozdania w sprawie spójności gospodarczej, społecznej i terytorialnej: przyszłość polityki spójności, Komunikat Komisji do Parlamentu Europejskiego, Rady Europejskiego Komitetu Ekonomiczno-społecznego, Komitetu Regionów oraz Europejskiego Banku Inwestycyjnego, Komisja Europejska, Bruksela, COM(2010) 642/3. 
Zathey M. (2004), Proces suburbanizacji mieszkaniowej i symptomy segregacji społecznej w otoczeniu Wrocławia, „Wrocław 2000 Plus”, nr 2, s. 94-106.

Zborowski A., Chaberko T., Gałka J., Grad N., Kretowicz P. (2008), Procesy suburbanizacji rezydencjonalnej w województwie małopolskim, [w:] Wnioski i rekomendacje, http://www. Polityka rozwoju.obserwatoria.malopolska.pl/Files.mvc/208/ROZDZIA\%C5\%81_ V_ Wnioski_i_rekomendacje.pdf, Kraków 2008, s. 473-516.

Zimnicka A. (2006), Przestrzenie publiczne miasta w dobie suburbanizacji-obszar metropolitalny Szczecina, PAN, Kraków.

Zimnicka A., Czernik L. (2007), Kształtowanie przestrzeni wsi podmiejskiej na przykładzie obszaru oddziaływania miasta Szczecin, Wydawnictwo Hogben, Szczecin, http://strategie.zut. edu.pl/_img /useruploads/files/13233797981874547795.pdf.

Zuziak Z. (2005), Strefa podmiejska w architekturze miasta. W strone nowej architektoniki regionu miejskiego, [w:] P. Lorens (red.), Problem suburbanizacji, Urbanista, Warszawa, s. 17-33.

Żuber, P. (2011), Początki polityki miejskiej-koncepcja przyszłej krajowej polityki miejskiej w Polsce, V Międzynarodowa Konferencja „Miasto 2011 - zarządzanie przestrzenią miasta", Ministerstwo Rozwoju Regionalnego, Katowice.

Krystian Heffner, prof., dr hab., Katedra Gospodarki Przestrzennej, Uniwersytet Ekonomiczny w Katowicach 